\title{
A longitudinal building fabric and energy performance analysis of two homes built to different energy principles
}

Julio Bros-Williamson ${ }^{\mathrm{a}, \mathrm{b},}{ }^{\mathrm{k}}$, Celine Garnier ${ }^{\mathrm{a}, \mathrm{b}}$, John I Currie ${ }^{\mathrm{a}, \mathrm{b}}$

a Scottish Energy Centre, Institute for Sustainable Construction, 42 Colinton Rd, Edinburgh, Scotland, UK, EH10 5BT

b School of Engineering and Built Environment, Edinburgh Napier University, 10 Colinton Rd, Edinburgh, Scotland, UK, EH10 5DT,

e-mail: \{j.broswilliamson, c.garnier, j.currie\} @napier.ac.uk, web: http://www.napier.ac.uk

${ }^{*}$ Denotes corresponding author

\section{Abstract}

This paper reports on the building performance monitoring and annual energy demand of two homes built side-by-side over an occupancy period of three years. The study compares the results from on-site monitoring against the assumed parameters and calculations from compliance modelling at design stage. It focuses on the differences and impact of occupancy behaviour, weather conditions, quality of construction and operation which contribute to an increase in energy consumption creating a gap in performance between design and actual. The results from the study show disparities in the fabric performance reflecting on the overall consumption of energy. This longitudinal analysis highlights how building performance needs to be evaluated over longer periods in order to fully understand how homes and their occupants operate and consume energy. The impact of the real performance of homes in Scotland over longer periods needs to become standardised, and a mechanism for feedback into regulatory mechanisms and construction practices applied, if carbon emission targets are to be met.

Keywords: Post-occupancy; building performance; energy; social housing; longitudinal studies. 


\section{1. Introduction}

2 The analysis of energy consumption and carbon emissions from buildings has been well

3 documented, particularly domestic properties subject to reduced performance levels [1-6].

4 According to Itard \& Meijer [7], in the EU 30\% of energy use comes from the residential sector

5 where $57 \%$ is consumed by space heating, $25 \%$ for water heating, $7 \%$ cooking and $11 \%$

6 electrical appliances. In Scotland, excluding the transport sector, 40\% of total energy

7 consumption (electricity and heat) is consumed domestically [8]. The above figures show that

8 the energy performance of existing and new stock residential buildings is of concern and

9 creating new policies and addressing the technical and social issues around them should be

10 of importance.

11 To address these issues, the Energy Performance of Buildings Directive (EPBD) 2002/91/EC

12 and its recast 2010/31/EC [9] requires each Member State to evaluate and certify their

13 buildings. These guidelines introduced the use of Nearly Zero Energy Buildings (NZEB) in

142010 , suggesting low energy demand linked with on-site renewable energy use [10]. The

15 UK's approach introduced the Code for Sustainable Homes (CfSH) in England \& Wales now

16 enforced in Part L Building Regulations [11] [12] and in Scotland the Section 7 Sustainability

17 [13] in the Scottish Building Standards (SBS) Technical Handbooks as recommended by

18 Sullivan [14] and Zero Carbon Homes [15] [16]. For energy calculations the National

19 Calculation Methodology (NCM) created the Standard Assessment Procedure (SAP)

20 generating Energy Performance Certificates (EPC) [17] [18] [19]. EPC results have become

21 the commercial and analytical method of understanding building performance as discussed

22 by Sutherland et al. [20], SBS [21] and Castellano et al. [22]. 
23 There are other EU standards aligned to the NZEB criteria. An example is the Passivhaus

24 standard, seen as being a rigorous method of minimising heat loss through a highly insulated

25 envelope, its design and construction criteria is explained fully by Feist et al.[23] \& Müller \&

26 Berker [24]. It relies on a hybrid heating system evaluated with its own calculation method

27 called the Passivhaus Planning Package (PHPP) [25] [26].

28 The aim of this study is to assess the performance of two homes during three years of

29 occupation and to learn if new and innovative building methods of construction are performing 30 as expected. Results from monitoring are presented and analysed, later compared against 31 regional benchmarks. This comprehensive measurement of building fabric and energy 32 consumption provides an insight into the impact of identified issues in low energy homes, 33 such as incompatibilities between the as-designed calculations and the as-built occupant 34 behaviour.

35 This study is significant because it equally assesses two homes that have performed over a 36 period of occupation. Most studies report on one property and its performance [26] or have 37 uncommon elements to compare against and are apart from each other [27] [28]. Their 38 proximity, placement, orientation, wind exposure and solar incidence, make these homes 39 worthy of comparison. Occupation and dwelling demographic is also distinct throughout this 40 study; resident numbers and hours of use have remained marginally unchanged, allowing for 41 a straightforward comparison between years, unpresented in the social housing sector.

\section{Literature review}

43 Despite the rigorous calculation process adopted in the UK and by the Passivhaus standard, 44 making sure homes have been built as-designed and calculated has not been a streamlined 45 process. Many studies in the UK and other EU countries have noticed a gap in performance 
46 demonstrating discrepancies between the calculated energy use and the actual energy

47 consumed [26], [29], [30].

48 Performance gap has been largely attributed to the design stage, particularly the proficiency 49 and quality of the energy calculation [31] [32]. de Wilde [31] highlights faults that overestimate 50 energy requirements such as accuracy and proficiency of the thermal compliance model.

51 Other issues have been studied such as accuracy of the manufacturer's energy efficiency 52 data for technology and materials [34] [35], complexity of original design [36,37], badly 53 assembled and interpreted thermal details during the construction process [38], poor 54 supervision and site communication between main contractors and sub-contractors [39] and 55 also installed inefficiencies and complicated controls [40] [41].

56 Occupant behaviour also contributes to disguised energy use often unaccounted for. Recent 57 studies identifying behaviour patterns have contributed to the performance of low carbon 58 homes [42]. Thermal comfort and the energy rebound effect are also relevant [43], [44-46]. 59 These occupant related issues are difficult to predict [31], [47] and Post Occupancy 60 Evaluations (POE) help to measure the effect of occupant behaviour. Techniques for 61 assessing buildings and occupants revealing avoidable waste, bad maintenance, wrong 62 occupant training, and bad management have provided evidential data of buildings 63 performance [47,48], [49-52].

64 Further tests at post-construction stage and after occupancy to assess the building fabric 65 quality and services efficiency are required to realistically assess buildings against as66 designed calculations, preferably after whole twelve month periods [29,53]. Building fabric

67 performance and energy consumption while homes are occupied are effective evaluations 68 [54]. Techniques such as; air leakage testing, in-situ U-value of selected components, infra- 
69 red thermography and internal/ external hygrothermal monitoring [1], [33], [47] can 70 demonstrate performance. Other techniques such as co-heating and tracer gas decay used

71 in other studies [26,29], deemed to be important but impractical in occupied dwellings.

72 Also essential to recognising building performance is analysing actual energy demand from 73 regulated and un-regulated electricity use and space and water heating needs. Legislation 74 on efficient building fabric and services has considerably decreased energy use for heating, 75 however electricity demand has risen as a result of increased use of appliances in households 76 [55] questioning the real operational performance of buildings once occupied. The current 77 compliance model used in the UK (SAP) [18] calculates heating needs as well as regulated 78 electrical demand, omitting un-regulated electrical demand from household appliances. This 79 creates issues surrounding the direct comparison of delivered electrical energy against the 80 assumed at design stage [18]. For comparison purposes benchmarks and similar archetype 81 and household occupancy types are a useful method to account for total electricity use in 82 households. Yohanis et al. [56] have developed a correlation between average annual 83 electricity consumption and floor area of representative dwelling types. White et al., [57], 84 White, [58] and Zimmermann et al. [59] obtained household energy consumption values 85 based on survey-reported expenditure and owner-occupier domestic appliance use, useful 86 as consumption benchmarks. Studies by DECC, [46] and The Scottish Government, [8] use 87 benchmarks of sub-national household energy consumption statistics, including the National 88 Energy Efficiency Data Framework (NEED) that considers lower domestic meter ranges and 89 the removal of estimated meter readings [61]. A comparison of these benchmarks can be 90 seen in appendix B in this paper. 
93 The two homes analysed in this paper are part of the Housing Innovation Showcase (HIS),

94 an award winning housing development by Kingdom Housing Association (KHA). It

95 comprised of twenty seven homes in ten blocks using ten different methods of construction

96 [62] [63]. A site plan and a description of the systems can be seen in Figure 1 and Table 1

97 where the case study dwellings are highlighted. A front elevation of both homes is shown in

98 Figure 2.

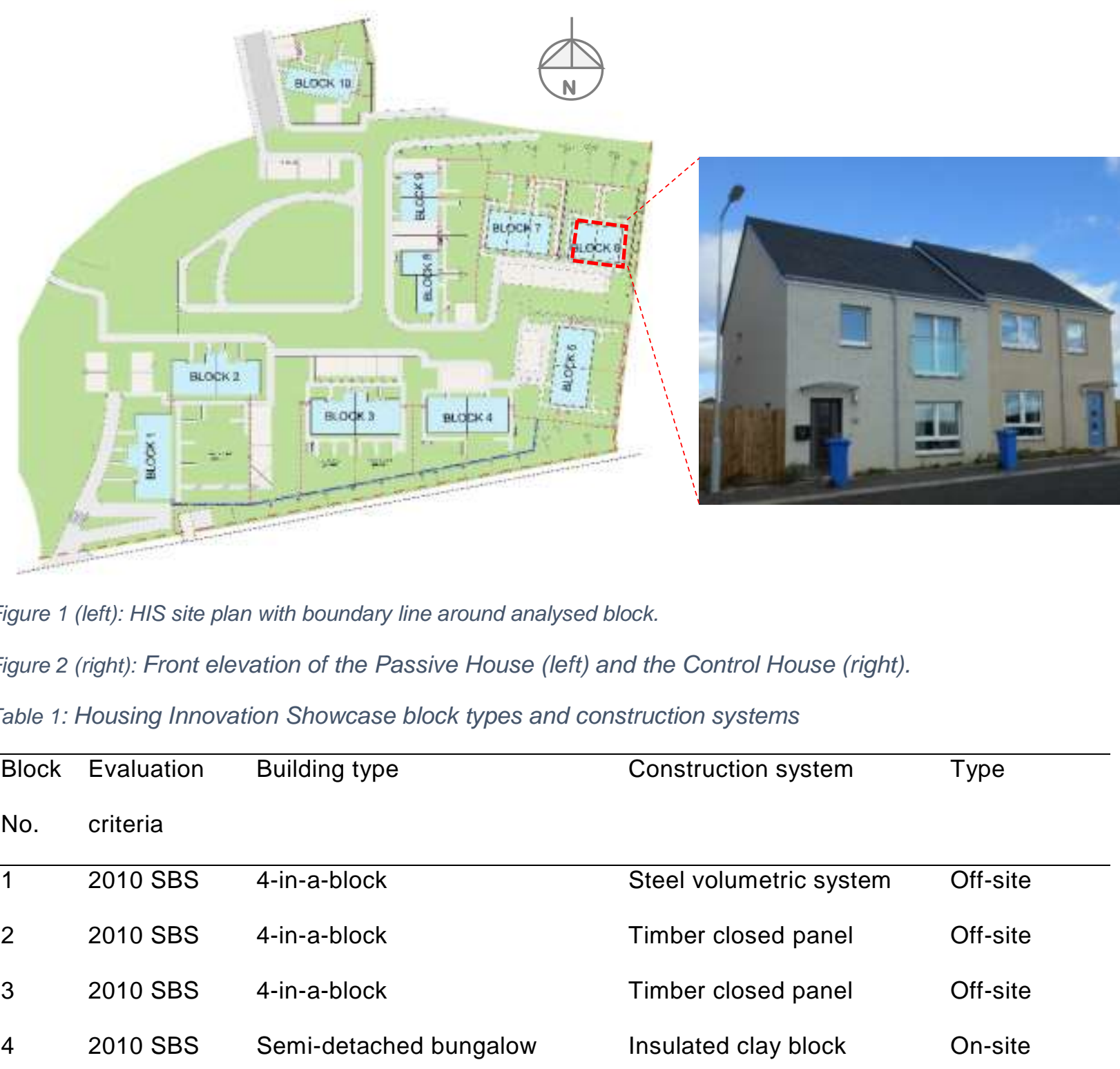




\begin{tabular}{lllll}
5 & 2010 SBS & Semi-detached bungalow & SIP (timber) & Off-site \\
\hline 6 & 2010 SBS \& & Semi-detached 2 storey house & Timber open/ closed panel & On \& Off-site \\
& Passivhaus & & & \\
\hline 7 & 2010 SBS & Semi-detached 2 storey house & Timber closed panel & Off-site \\
8 & 2010 SBS & Semi-detached 2 storey house & Timber closed panel - & Off-site \\
9 & 2010 SBS & Semi-detached 2 storey house & Timber closed panel & Off-site \\
10 & 2010 SBS & Semi-detached 2 storey house & Concrete wall-form & On-site
\end{tabular}

104 One home, evaluated using SAP version 9.90 (SAP2009), is the control house $(\mathrm{CH})$ that 105 epitomised current KHA housing typology and specification designed to meet 2010 Scottish 106 Building Standards [64]. Adjacent is the second property designed to the Passivhaus (PH) 107 standard also evaluated using SAP2009 and PHPP energy tool. The two dwellings share the 108 same orientation and configuration, also built by the same contractor. Differences include 109 wall system and the energy efficiency methods implemented at design stage. The homes 110 although similar in appearance have distinct differences as detailed in Figures 3 and 4 and 111 Table 2.
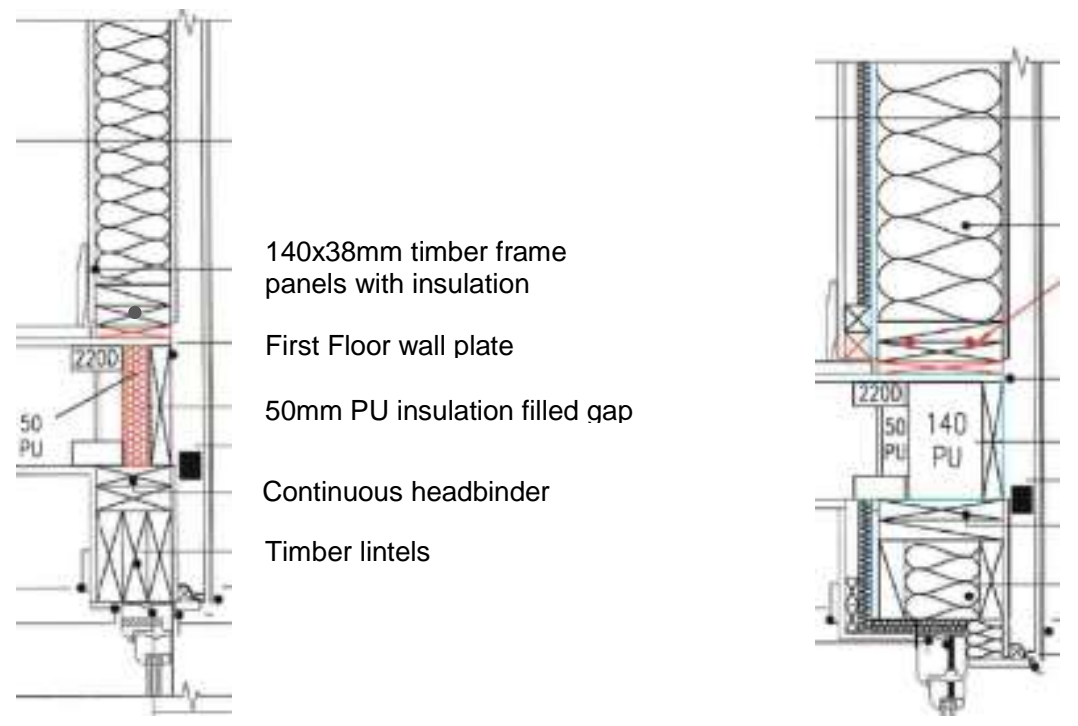

$235 \times 38 \mathrm{~mm}$ injected polyurethane insulation

First Floor wall plate

140mm PU insulation filled gap

Continuous headbinder

Timber lintels with injected insulation 
114 Table 2: Wall assembly description

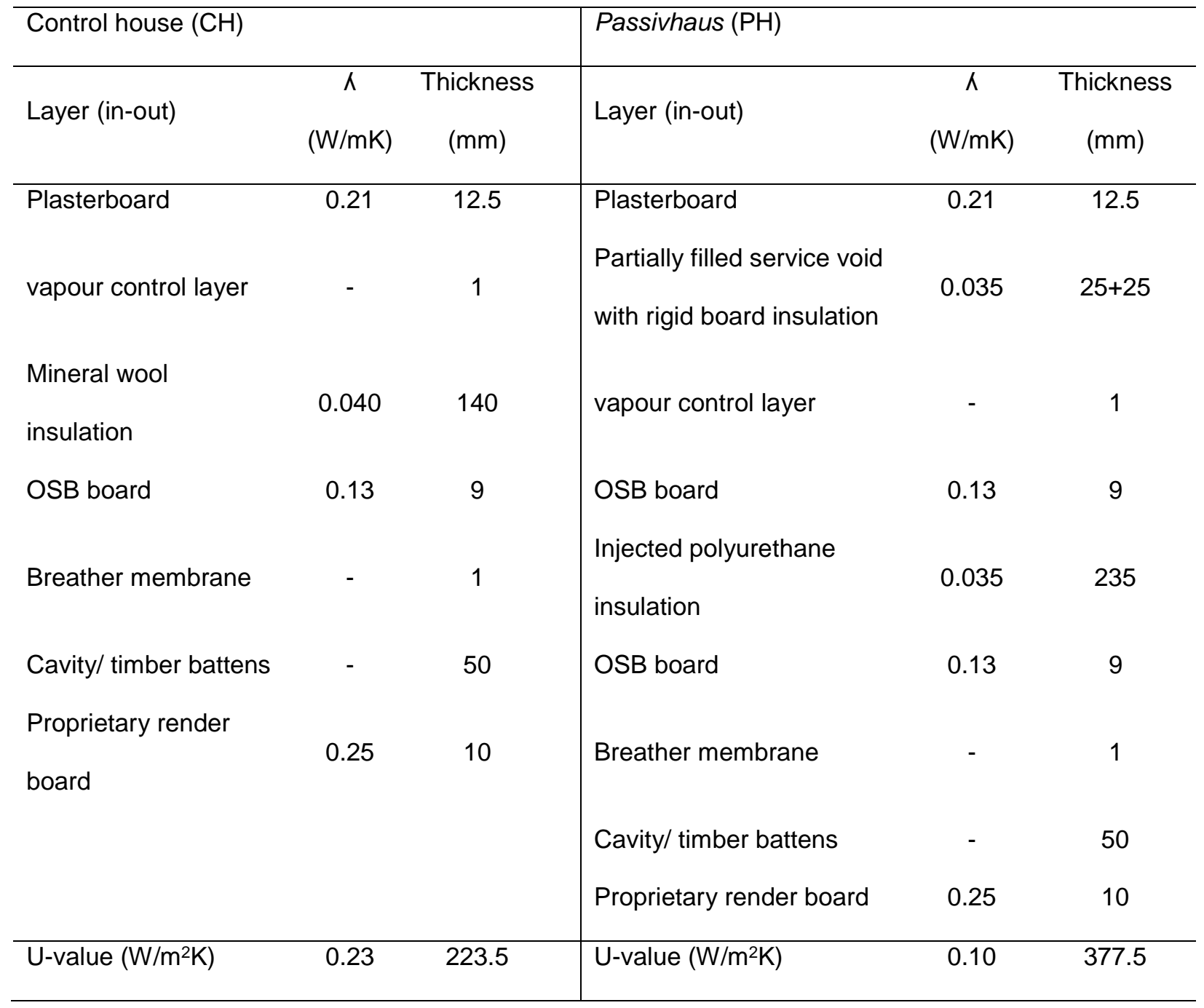

115

116 Table 3 shows the properties specifications and design parameters implemented in the

117 SAP2009 and PHPP calculations.

118 Table 3: Comparison of design specification and targets, Control house and Passivhaus

\begin{tabular}{lll}
\hline & Control house $(\mathrm{CH})$ & Passivhaus $(\mathrm{PH})$ \\
\hline Certification & 2010 SBS & 10W/m2 peak load, PHPP \\
& certified, 2010 SBS \\
Design Strategy & Baseline for HIS & Maximising the benefit of \\
& & solar \& internal gains
\end{tabular}




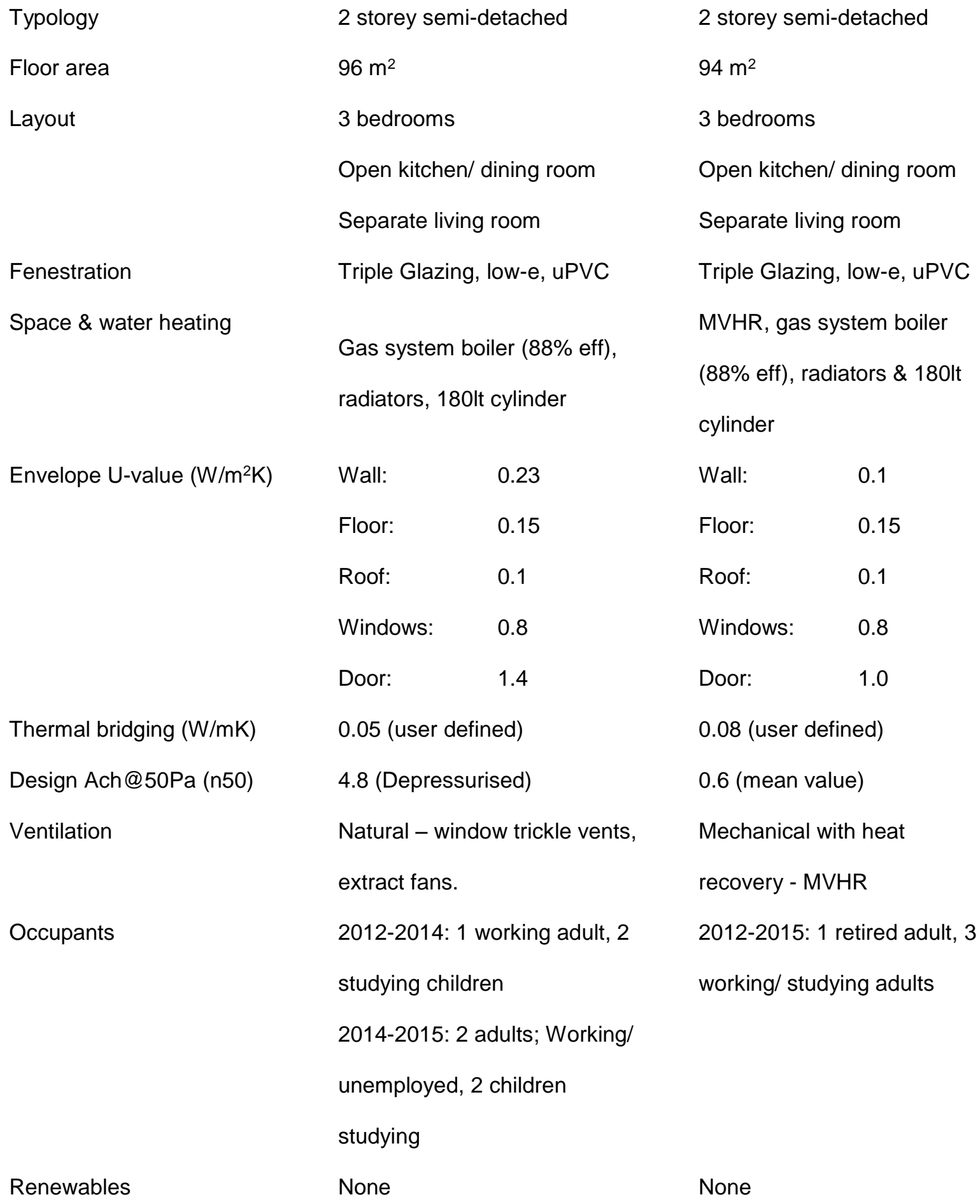

\section{Methodology}

121 This study includes fabric performance evaluation and energy demand monitoring since the 122 dwellings completion in May 2012 to the last monitoring period in December 2015. Data has 
been retrieved by visiting the properties on a continual basis before occupation followed by an annual inspection and data retrieval period. Property evaluation started in May 2012 where 125 air leakage testing was performed. Handover took place in the latter days of June. The 126 research started by deploying testing equipment and conducting an early occupation study 127 during winter 2012. The measurements included in-situ U-value testing of building 128 components and internal/ external infra-red surveys of the properties. At handover, energy 129 meter readings were taken combined with the commissioning and deployment of In-home 130 Displays (IHD) for logging hourly energy consumption. Subsequently, energy retrieval took 131 place on a yearly basis in July 2013, 2014 and 2015 together with occupant surveys and 132 deployment of temperature and humidity loggers. A second phase of fabric performance 133 monitoring took place in November and December 2014 repeating the wall in-situ U-value 134 testing and air leakage tests. Appendix A shows the technical elements of the monitoring 135 equipment.

\subsection{Air leakage and smoke tests}

137 The properties were assessed at key stages of the pre and post occupation period by using 138 the standard Blower Door and fan test equipment, as seen in Figure 5. Accuracy of the tests 139 results is based on the BS EN Standard 13829:2001 (BS EN, 2001) and dependent on test 140 equipment as shown in Appendix A [66]. Smoke test were conducted in 2014 using a smoke141 stick identifying air flows, drafts and the direction and main air leakage points [2]. Air tightness 142 tests can identify air leakage pathways where uncontrolled flow of air passes through cracks, 143 around openings, gaps in air-tight layers and service penetrations [67-70]. 


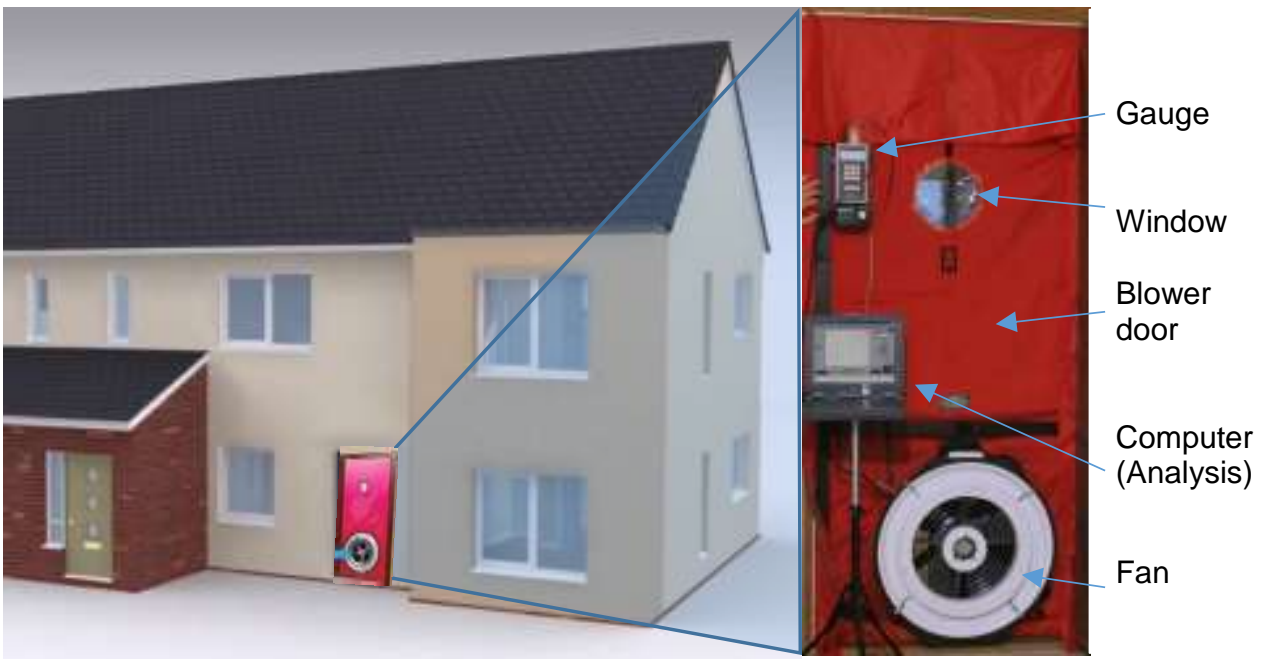

153

Figure 5: Air permeability blower door testing equipment (Source: Building animation LCBTG [71])

4.2 In-situ U-value

155 In-situ U-value tests were conducted during winter 2012/13 and winter 2014/15 using Grant 156 Squirrel data loggers with Hukseflux HFP01 thermopile-based heat flux transducers and four 157 K-type thermocouples, deployed at five minute intervals for a period of between 14 and 21 158 days. Figure 6 shows where equipment was mounted. 
Heat Flux Mat at

$2000 \mathrm{~mm}+\mathrm{FFL}$.

Thermocouple

attached for

Surface

temperature

Heat Flux Mat at

$1000 \mathrm{~mm}+\mathrm{FFL}$.

Thermocouple

attached for

Surface

temperature

Internal ambient

Temperature -

Thermocouples

and Tinytag

logger
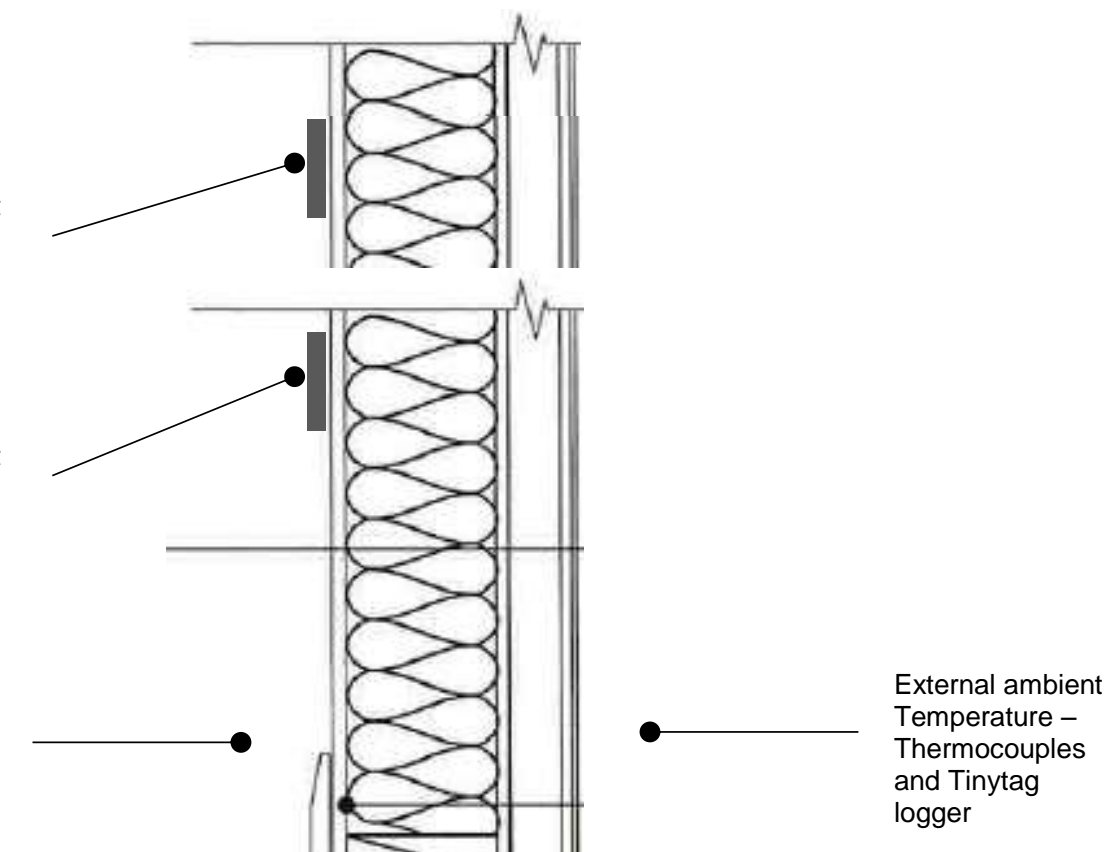

Figure 6: Typical positioning of HFM, thermocouples and temperature loggers - example in Control House

161 The testing complied with BS ISO 9869:2014 guidelines and calculations [72] [73] as seen in 162 Figures 7, 8 \& 9. Reliable results are obtained with a temperature differential $(\Delta \mathrm{T})$ of $>10^{\circ} \mathrm{C}$ across the building element.

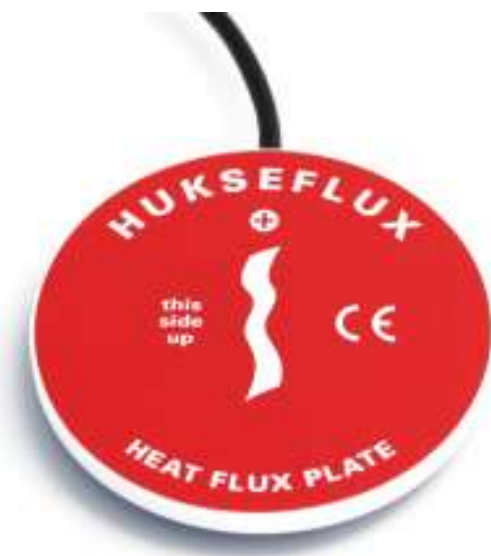

164
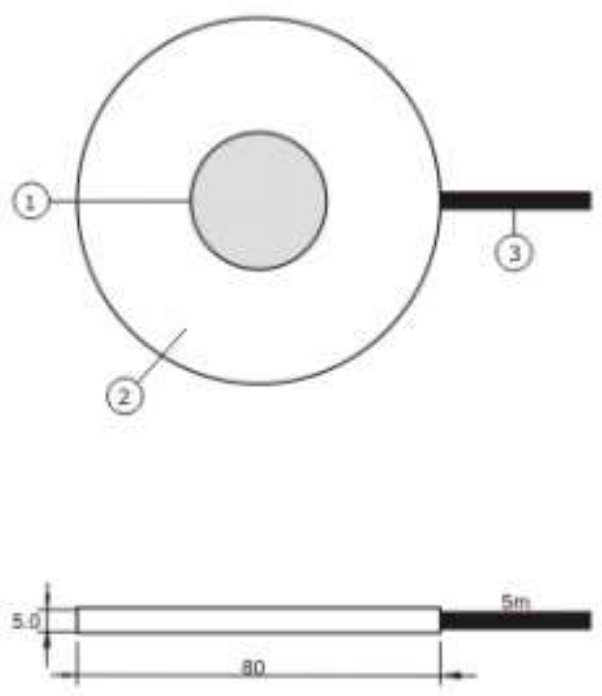

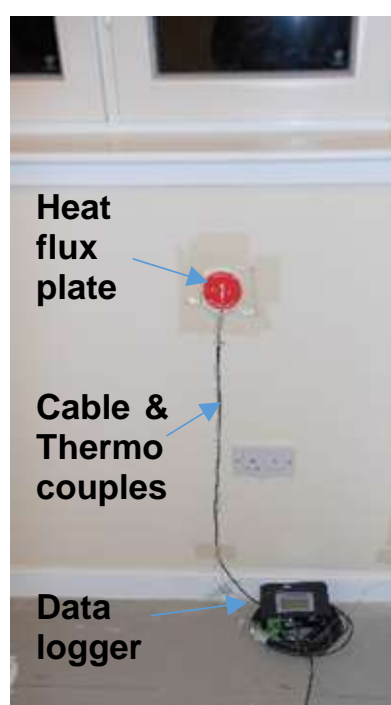

Figure 7 (left): Typical HFP sensor by Hukseflux. 
Figure 8 (centre): Sensor diagram: (1) Sensor area; (2) guard of ceramics-plastic composite; (3) cable connected to data logger [74].

Figure 9 (right): Typical installation on external wall - affixed internally.

All measured values undergo an error analysis which suggest small errors may exist in such tests of between $5-8 \%$ within the uncertainty of the equipment's calibration. The calculation process and results analysis is dependent on the temperature data retrieved [73] [75].

\subsection{Infra-red thermography}

The survey was conducted on both properties during the first heating period. It included an internal and external survey concerning all elevations of the dwellings with close-up thermograms for specific analysis. Infra-red thermography is a non-destructive qualitative test carried out with a thermal imaging camera following the methodology in BS EN 13187: 1999 [76]. It is a tool that establishes surface temperature variations caused by building defects in insulation layers or thermal bridging [77] \& [78]. Methodology of testing and the analysis of thermograms is discussed by Hart, [79], Lo \& Choi, [80] \& Guerra-Santin et al., [33].

\subsection{Indoor and outdoor environmental conditions}

Hourly temperature and relative humidity conditions were collected using Tinytag data loggers in living rooms in both dwellings from June 2012 to December 2015. External readings for the periods from June 2012 to September 2014 were collected by a nearby weather station located in Crossford, Dunfermline, Fife, approximately 4.5 miles from the properties. From the period of September 2014 to December 2015 a site located Logic Energy LeNET Mobile weather station was deployed 60 meters from the properties. It recorded; temperature, relative humidity, wind speed, wind direction, barometric pressure, and southern solar radiation. 
191 Delivered energy consumption data for each dwelling was obtained from In-home displays 192 (IHD) supported by a reconciliation of metered energy use, to obtain total gas and electricity 193 consumed over three years at twelve monthly intervals [81] [82]. A comparison was made 194 between the design performance indices calculated by SAP2009 for space, water heating 195 and electrical use against delivered energy for the three years of occupation. This 196 assessment of normalised performance indices is explained in the BS EN15217:2007 [83] 197 and discussed by Castellano et al., [22], Burman et al., [58] and O'Leary et al., [90]. The 198 consumed yearly energy demand $\left(\mathrm{kWh} / \mathrm{m}^{2} / \mathrm{yr}\right)$, total yearly carbon emissions $\left(\mathrm{kgCO}_{2} / \mathrm{m}^{2} / \mathrm{yr}\right)$ 199 and total yearly cost of energy use $(€ / y r)$ were compared against as-designed calculations 200 and Great Britain and Scottish benchmarks shown in Appendix B.

\section{5. Results}

202 In this section the results of the three yearlong monitoring study are presented. To begin with, 203 section 5.1 describes the as-designed results and the differences observed with the as-built 204 conditions. It follows the fabric performance evaluation in section 5.2 presenting results from 205 in-situ U-value measurements, air leakage and infra-red thermography. This section informs 206 key variables that affect the properties energy demand over the period of monitoring. Section 2075.3 compares delivered energy against the design calculations and other benchmarks in 208 Appendix B. The final analysis comes in section 5.4 comparing cost and carbon performance.

$209 \quad 5.1 \quad$ Design stage results

210 During the design stage, SAP2009 compliance models and PHPP for certification calculated 211 the total annual expected gas and electricity (regulated) consumption, as well as the total 
212 primary energy required and the carbon emission rate of the two dwellings. Table 4 below 213 presents the results for the two analysed dwellings.

214 Table 4: SAP2009 \& PHPP design results for SBS 2010 compliance

\begin{tabular}{|c|c|c|c|}
\hline \multirow{2}{*}{ Evaluation } & \multirow{2}{*}{$\begin{array}{c}\text { Control House } \\
\text { SAP2009 }\end{array}$} & \multicolumn{2}{|c|}{ Passivhaus } \\
\hline & & SAP2009 & PHPP \\
\hline $\begin{array}{l}\text { Annual Space } \\
\text { Heating (kWh/m²/yr) }\end{array}$ & 33.7 & 19.45 & 16.0 \\
\hline $\begin{array}{l}\text { Annual Water } \\
\text { Heating (kWh/m²/yr) }\end{array}$ & 26.2 & 30.0 & 31.7 \\
\hline $\begin{array}{l}\text { Annual Electricity } \\
\left(\mathrm{kWh} / \mathrm{m}^{2} / \mathrm{yr}\right)\end{array}$ & 8.2 & 9.1 & 5.36 \\
\hline $\begin{array}{l}\text { Annual Total } \\
\left(\mathrm{kWh} / \mathrm{m}^{2} / \mathrm{yr}\right)\end{array}$ & 68.1 & 55.1 & 56.6 \\
\hline $\begin{array}{l}\text { Primary energy } \\
\left(\mathrm{kWh} / \mathrm{m}^{2} / \mathrm{yr}\right)\end{array}$ & 79.85 & 72.66 & 66.7 \\
\hline $\begin{array}{l}\mathrm{CO}_{2} \text { emissions } \\
\left(\mathrm{kgCO}_{2} / \mathrm{m}^{2} / \mathrm{yr}\right)\end{array}$ & 16.3 & 14.8 & 15.4 \\
\hline SAP rating & 84 & 84 & - \\
\hline SAP El rating & 85 & 88 & - \\
\hline
\end{tabular}

215

216 The results obtained in Table 4 are based on conventional values broadly dependant on 217 buildings location, floor space and occupancy. During the analysis of the calculated results it 218 was observed that these values were not representative of the as-built conditions. In 219 SAP2009 the assumed number of occupants is based on the total floor area (TFA) of the 220 living room, providing figures for internal gains, hot water demand and electrical regulated 221 energy. Although assumed, in reality occupant behaviour can vary, both in quantity and hours 222 of occupation. For this model, the calculation resulted in having 2.71 occupants for the $\mathrm{CH}$ 
223 and 2.68 for the PH. PHPP similarly calculates occupancy using the total floor area assuming 224 a limit of $35 \mathrm{~m}^{2} /$ person, thus 2.6 occupants is used. In reality the occupancy of the homes 225 differ. The $\mathrm{CH}$ has two children and one regular adult with intermediate occupancy by another 226 adult. The PH has four adults with an intermediate occupancy dependant on employment.

227 For the external weather applied to the calculation process, SAP2009 uses monthly values 228 and PHPP uses a worst case scenario weather file $[85,86]$. Figure 10 shows external 229 temperature during the three years of monitoring. The average figures show that 230 temperatures during the three years of monitoring are similar to the values used in PHPP but 231 lower than those used in SAP2009. Other determinants are wind speed and solar radiation 232 where more variations were observed that impact the actual performance compared with the 233 calculations.

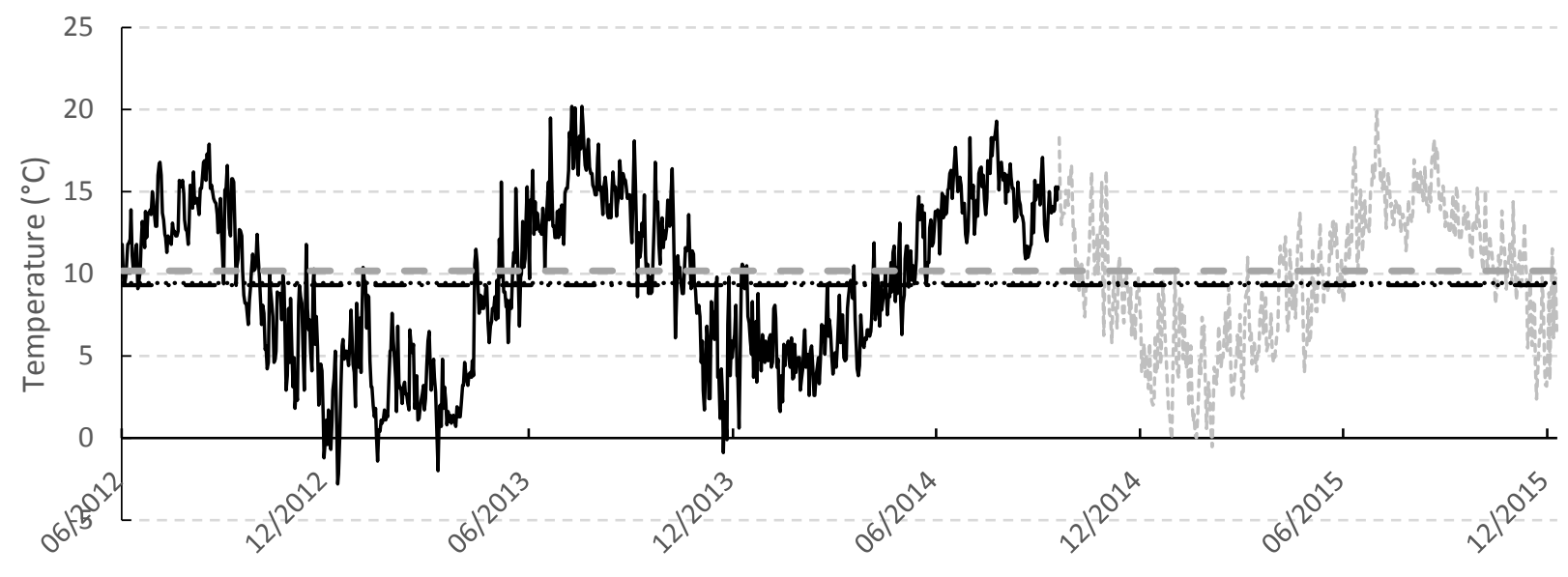

235 Figure 10: Average monthly dry bulb temperature $\left({ }^{\circ} \mathrm{C}\right)$, Crossford, Fife \& on-site HIS weather stations

236 The internal design temperature used by SAP2009 of $21^{\circ} \mathrm{C}$ also differ from the actual 237 experienced. PHPP calculations use two temperatures, $20^{\circ} \mathrm{C}$ during winter months for 238 heating demand calculations and $25^{\circ} \mathrm{C}$ during summer months for cooling demand 239 calculations. Temperatures above $21^{\circ} \mathrm{C}$ in both dwellings occur during nine months 
240 throughout the three years of study, particularly in July and August. Figure 11 shows the $\mathrm{CH}$ 241 internal temperatures fall below the comfort range stated by CIBSE (2015) between 20 and $24226^{\circ} \mathrm{C}$, with low and high readings of $15^{\circ} \mathrm{C}$ and $27^{\circ} \mathrm{C}$ respectively. However the average 243 throughout this period is in the lower range of the comfort level at $20.5^{\circ} \mathrm{C}$. The readings show 244 temperature is susceptible to fluctuations, particularly in the winter months.

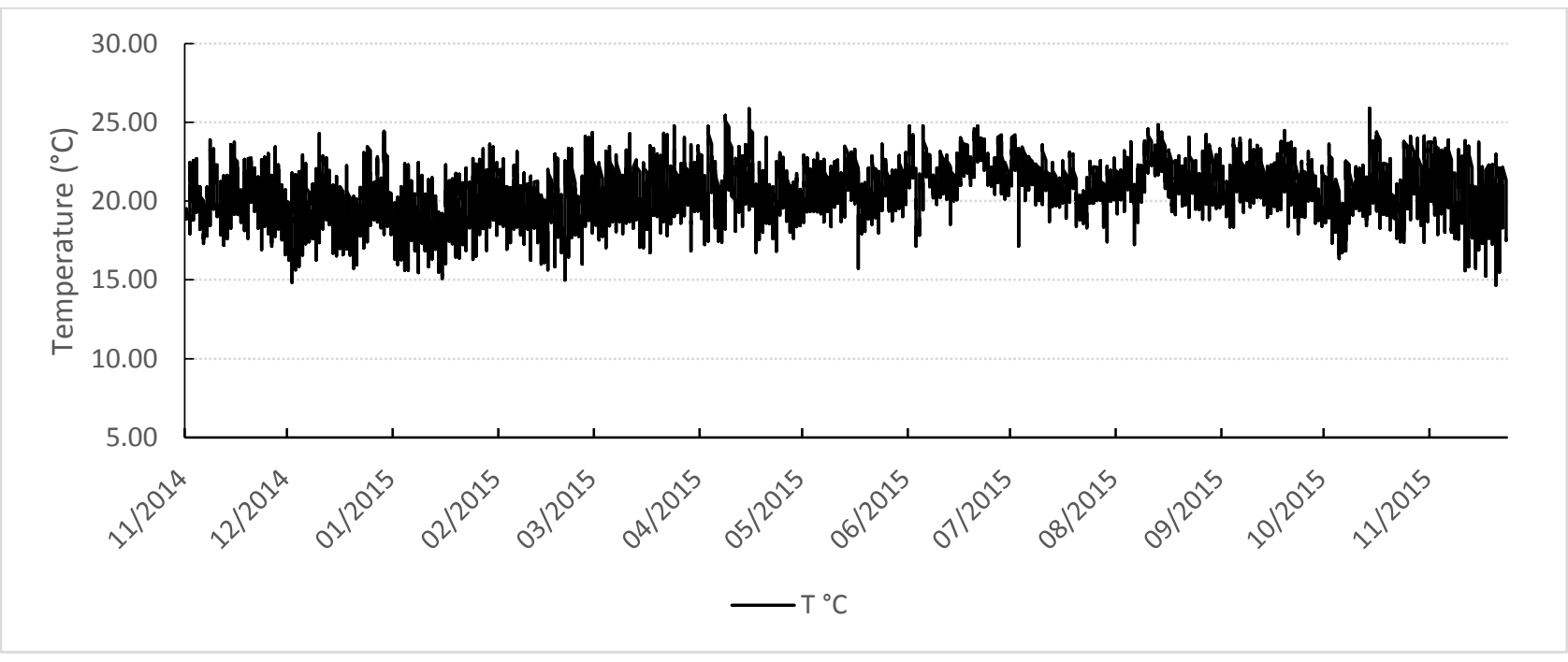

Figure 11: Control House internal environmental conditions between November 2014 \& December 2015

247 The internal temperature for the $\mathrm{PH}$ in Figure 12 appears condensed and with a lower 248 amplitude, meaning it hasn't been influenced by external fluctuations. Temperatures seldom 249 reach below $18^{\circ} \mathrm{C}$ however some higher temperatures are reached closer to $27^{\circ} \mathrm{C}$ but 250 generally clustered to the mean of $22^{\circ} \mathrm{C}$. 


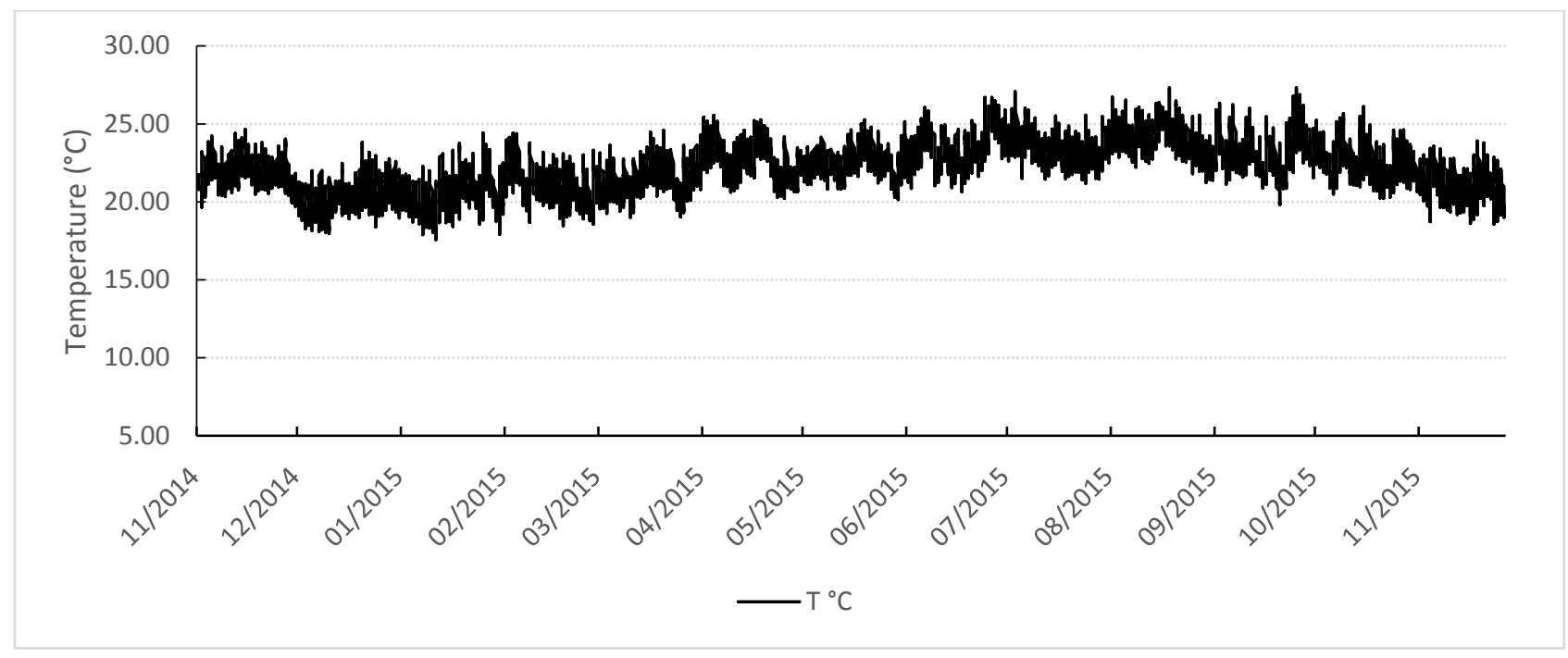

Figure 12: Passivhaus internal environmental conditions between November 2014 \& December 2015

$254 \quad 5.2 \quad$ Fabric performance monitoring

$255 \quad$ 5.2.1 Air Leakage and smoke tests

256 Table 5 shows the comparison between the two tests conducted to measure the air leakage 257 rate of the dwellings. Three figures are shown worth comparing; the first is the assumed air 258 leakage used for compliance calculations, followed by the two in-situ tests performed.

Table 5: Summary table of air leakage results at post construction stages

\begin{tabular}{|c|c|c|c|c|c|c|c|c|c|c|c|}
\hline & \multicolumn{5}{|c|}{ Building characteristics } & \multicolumn{3}{|c|}{ Post-construction - 2012} & \multicolumn{3}{|c|}{ Post-construction - 2014} \\
\hline & $\begin{array}{l}\text { Floor } \\
\text { area } \\
\left(\mathrm{m}^{2}\right) \\
\end{array}$ & $\begin{array}{l}\text { Volume } \\
\left(\mathrm{m}^{3}\right)\end{array}$ & $\begin{array}{l}\text { Envelope } \\
\text { area }\left(\mathrm{m}^{2}\right)\end{array}$ & $\begin{array}{l}\text { Ratio } \\
\text { Vol/area }\end{array}$ & $\begin{array}{l}\text { Design Air } \\
\text { leakage rate } \\
(\mathrm{n} 50)\end{array}$ & $\begin{array}{l}\text { Flow } \\
@ 50 \mathrm{~Pa} \\
\left(\mathrm{~m}^{3} / \mathrm{h}\right) \\
\end{array}$ & $\begin{array}{l}\text { Air flow } \\
\text { exponent } \\
(\mathrm{n})\end{array}$ & $\begin{array}{l}\text { Air } \\
\text { leakage } \\
\text { rate }(\mathrm{n} 50)\end{array}$ & $\begin{array}{l}\text { Flow } \\
@ 50 \mathrm{~Pa} \\
\left(\mathrm{~m}^{3} / \mathrm{h}\right) \\
\end{array}$ & $\begin{array}{l}\text { Air flow } \\
\text { exponent } \\
(\mathrm{n})\end{array}$ & $\begin{array}{l}\text { Air } \\
\text { leakage } \\
\text { rate (n50) } \\
\end{array}$ \\
\hline $\mathrm{CH}$ & 96.92 & 247.15 & 238.00 & 0.96 & 4.8 & 871.98 & 0.650 & 3.5 & 958.5 & 0.656 & 3.88 \\
\hline $\mathrm{PH}$ & 93.96 & 232.00 & 224.00 & 0.97 & 0.6 & 123.11 & 0.813 & 0.53 & 468 & 0.666 & 2.01 \\
\hline
\end{tabular}

261 The results show significant changes between initial tests conducted prior occupation and 262 the tests two years after occupation. It has also shown differences in the design expected 263 figure compared with the post construction stages as observed in Figure 13. An interesting 
observation is the air flow exponent or the air flow regime through orifices in the dwelling in a scale of 0.5 to 1.0 (ATTMA, 2010). Larger apertures have a value closer to 0.5 whereas values closer to 1.0 demonstrates dispersed laminar air flow orifices. Tests conducted in 2012

267 and 2014 show small variations, however the $\mathrm{PH}$ has changed from having small orifices to 268 larger ones, created by the occupants with uncontrolled penetrations (picture hanging, etc) 269 or third party TV service penetrations.

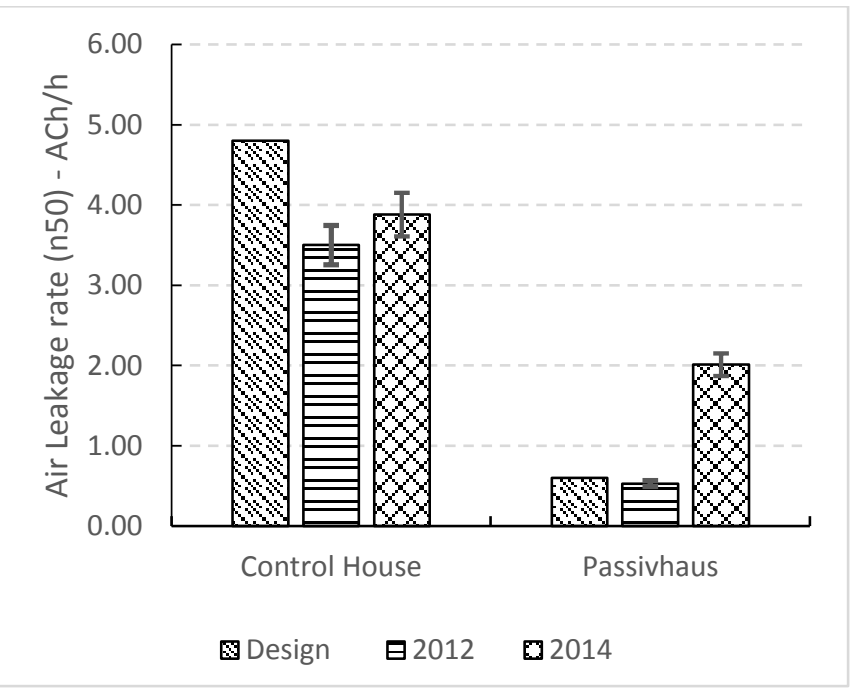

271 Figure 13: Graphical results between design and measurements air tightness

272 The smoke pencil test detected minor leakage areas, most were in the $\mathrm{CH}$ at junctions 273 between floor and wall at first floor level, gaps around attic hatch, leakage through and around 274 windows, doors and services penetrations as seen in Figures $14 \& 15$.
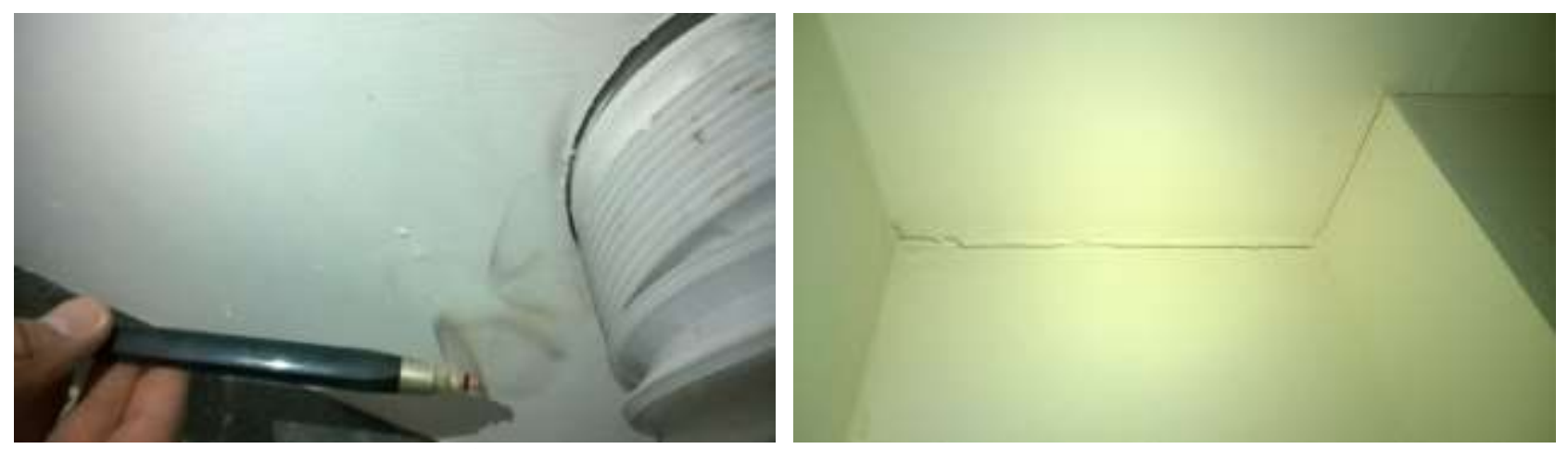

5.2.2 In-Situ U-value results 
277 The In-situ U-value monitoring was undertaken during the first winter in 2012 and two years 278 afterwards in the winter of 2014. Table 6 and Figure 16 show the results of the two tests 279 against the design calculations and SBS 2010 maximum permitted values for walls. 280

281 Table 6: U-value results compared with Design calculations and maximum U-values SBS, 2010.

U-value $\left(\mathrm{W} / \mathrm{m}^{2} \mathrm{~K}\right)$

\begin{tabular}{llll}
\hline SBS 2010 & Design & & \\
& & 2012 & 2014
\end{tabular}

\begin{tabular}{lllll}
\hline $\mathrm{CH}$ & 0.25 & 0.23 & 0.26 & 0.38 \\
$\mathrm{PH}$ & 0.25 & 0.10 & 0.12 & 0.11 \\
\hline
\end{tabular}

282

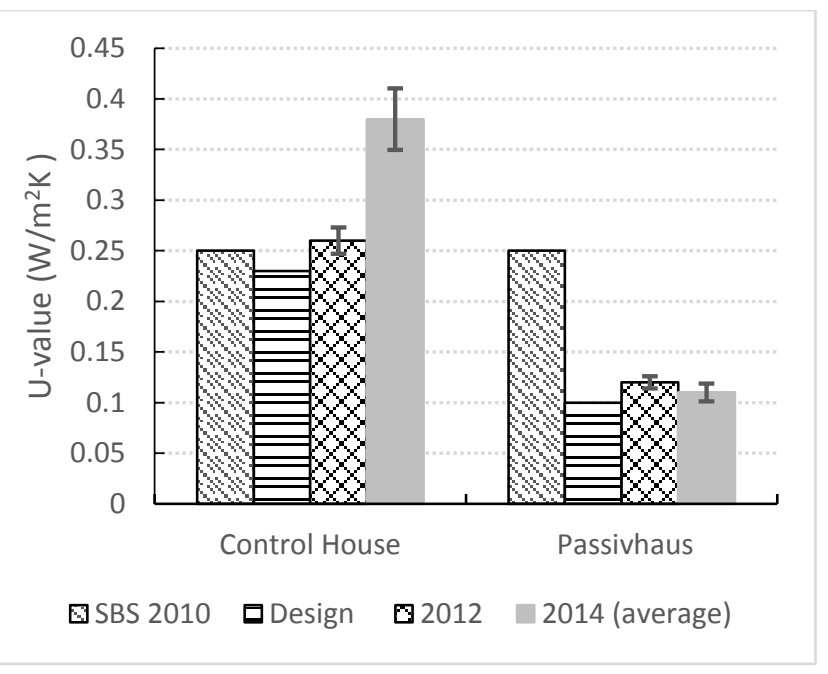

284 Figure 16: U-value results in comparison with design calculations and SBS 2010 maximum values

285 The $\mathrm{CH}$ has presented a $46 \%$ increase in thermal transmittance, however the $\mathrm{PH}$ has 286 remained consistent in the two tests with a minor decrease in transmittance attributed to the 287 accuracy of the tests.

5.2.3 Infra-red Thermography 
289 An infra-red thermography survey were conducted prior to handover and occupation. External 290 thermogram in Figure 17 easily distinguishes the two properties. On the left the PH property 291 shows lower surface temperatures than the $\mathrm{CH}$ on the right. Higher uneven temperatures on 292 the wall and around openings of the $\mathrm{CH}$ clearly indicate envelopes reduced capacity to limit 293 heat loss. The analysis of Figure 18 shows heat loss at the ceiling level of the front elevation 294 in the $\mathrm{CH}$.
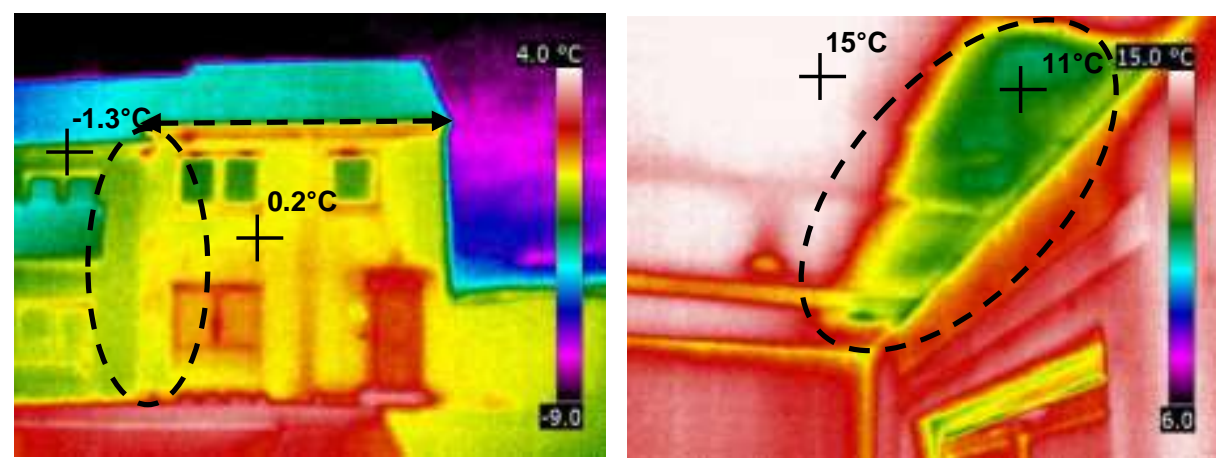

Figure 17 (left): External image of the $\mathrm{PH}$ and $\mathrm{CH}$. Figure 18 (right): Internal $\mathrm{CH}$ first floor ceiling in.

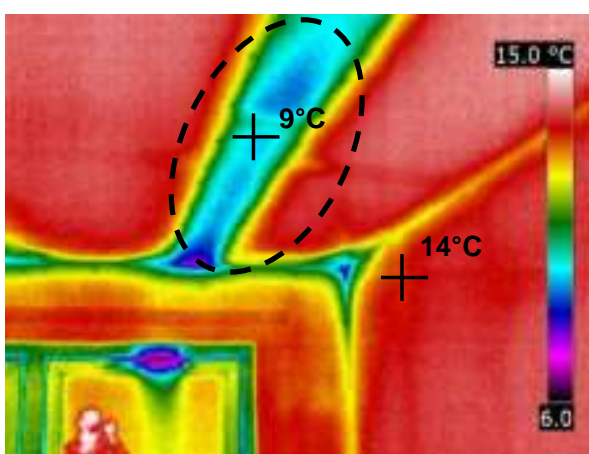

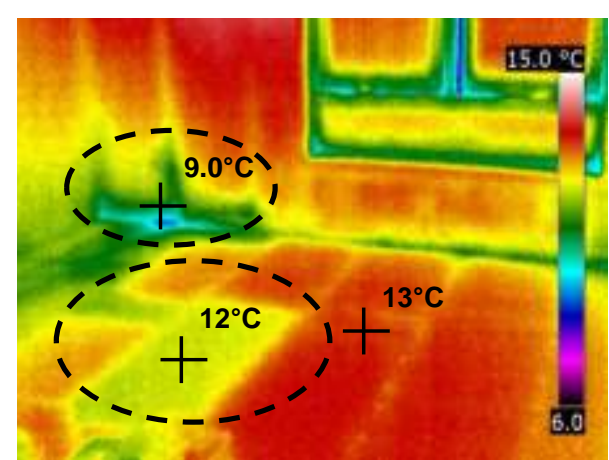

Figure 19 (left): Internal thermograms in the $\mathrm{CH} \quad$ Figure 20 (right): Ground floor heat loss in the $\mathrm{CH}$

Thermography is also good at evidencing thermal bridging, Figure 19 shows a thermogram taken of the $\mathrm{CH}$ first floor bedroom ceiling where timber joists are creating a linear thermal bridge. Thermogram in Figure 20 shows missing insulation between floor joists and also an air leakage pathway where missing insulation and an existing gap behind dry lining is causing heat loss. The PH has some deficiencies, despite being of low impact, Figure 21 shows 
304 missing insulation at the first floor ceiling and Figure 22 in the bathroom where a pipe or duct 305 detail creates heat loss.

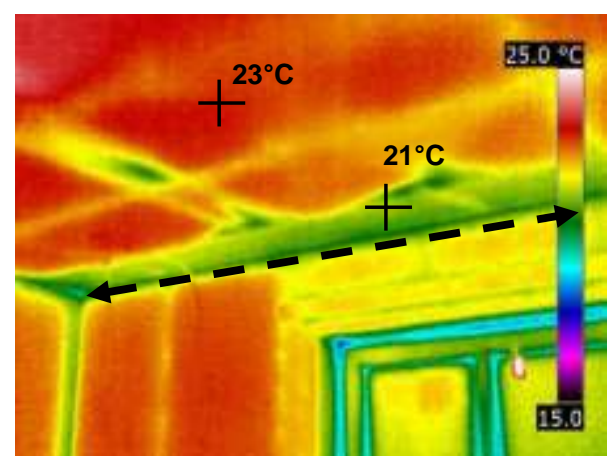

Figure 21 (left): PH: bedroom ceiling

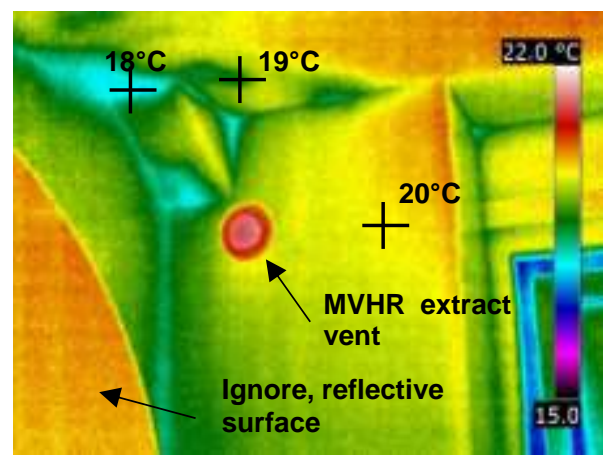

Figure 22 (right): PH: Bathroom junction

\subsection{Delivered energy performance}

The two analysed properties use natural gas as their main fuel for space and water heating.

310 Electricity is used for appliances, pumps, fans and lighting. The mechanical ventilation with 311 heat recovery (MVHR) unit in the Passivhaus provides recovered heat from the wet rooms 312 and is powered by electricity. Both properties have an electric shower in the ground floor 313 while other needs are provided by a system boiler and water cylinder. A back-up 3kW 314 immersion heater is also installed in the cylinder but rarely used by the residents.

316 The delivered electricity demand in each dwelling for each of the monitored years is shown

317 in Table 7. The electricity consumption data shows both regulated and unregulated sources.

318 Alongside the totals are benchmarks and calculations relative to the two dwellings. The PHPP 319 calculation allows appliances and cooking loads to be included in the criteria for evaluation. 320 It calculated that $1,755 \mathrm{kWh} / \mathrm{yr}\left(18.7 \mathrm{kWh} / \mathrm{m}^{2} / \mathrm{yr}\right)$ is used, a figure that is 2.5 times lower than 321 the total delivered for year one. The benchmark used from research by Yohanis et al., [62] of $40 \mathrm{kWh} / \mathrm{m}^{2} / \mathrm{yr}$ is $1,200 \mathrm{kWh} / \mathrm{yr}$ more than the $\mathrm{CH}$ delivered for year one, showing that the 
occupants were frugal in their use of electricity. The estimation used by Yohanis (ibid) is lower

by $600 \mathrm{kWh} / \mathrm{yr}$ than the three year average consumption for the $\mathrm{PH}$ and $800 \mathrm{kWh} / \mathrm{yr}$ lower than

325 the $\mathrm{CH}$.

Table 7: Total delivered electricity against benchmarks and calculations

\begin{tabular}{|c|c|c|c|c|c|c|c|c|c|}
\hline & \multicolumn{4}{|c|}{$\begin{array}{l}\text { Total delivered electricity } \\
(\mathrm{kWh} / \mathrm{yr})\end{array}$} & \multicolumn{5}{|c|}{ Benchmarks \& calculations $(\mathrm{kWh} / \mathrm{yr})$} \\
\hline & $\begin{array}{l}\text { Year } \\
1\end{array}$ & $\begin{array}{l}\text { Year } \\
2\end{array}$ & $\begin{array}{l}\text { Year } \\
3\end{array}$ & $\begin{array}{l}3 \text { year } \\
\text { average }\end{array}$ & $\begin{array}{l}\text { SAP2009 } \\
\text { (regulated } \\
\text { demand) }\end{array}$ & $\begin{array}{c}\text { PHPP } \\
\text { (Aux \& } \\
\text { appliances) }\end{array}$ & $\begin{array}{l}\text { Yohanis et } \\
\text { al. (2008) }\end{array}$ & $\begin{array}{c}\mathrm{GB} \\
\text { average }\end{array}$ & $\begin{array}{l}\text { Scottish } \\
\text { average }\end{array}$ \\
\hline & 2013 & 2014 & 2015 & & & & & & \\
\hline $\mathrm{CH}$ & 2,650 & 3,268 & 3,111 & 3,010 & 620 & - & 3,840 & & 3915 \\
\hline $\mathrm{PH}$ & 4,716 & 4,321 & 4,150 & 4,396 & 563 & 1,756 & 3,760 & 4,100 & 3,915 \\
\hline
\end{tabular}

327 Figure 23 compares the normalised electricity consumption during the three different years

328 of monitoring. Year one is often used as an adjustment period reflecting high energy use. The $329 \mathrm{PH}$ has consumed more electricity than the $\mathrm{CH}$ because of the larger hours of occupation 330 and number of adults living in the property together with the added appliances and technology 331 used.

332 The PHPP uses regulated and unregulated energy assumptions in its calculation. The 333 normalised figure used as a design comparison is $18.7 \mathrm{kWh} / \mathrm{m}^{2} / \mathrm{yr}$, more than half of the 334 benchmark used from Yohanis et al (ibid). Scottish and British averages are useful to place 335 the dwellings within a regional grouping, both of which are above the delivered demand. 


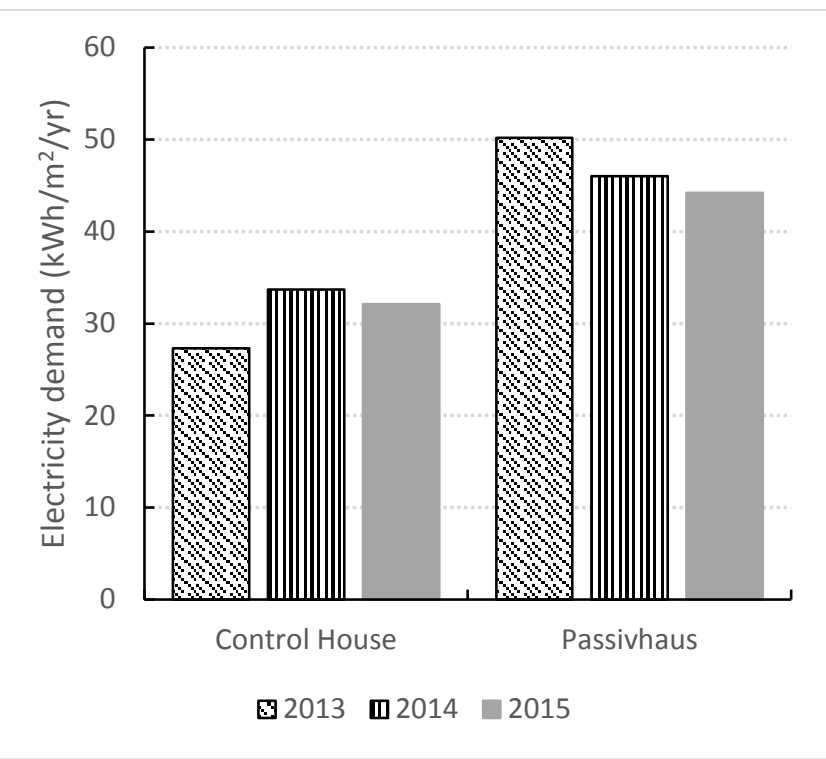

337 Figure 23: Distribution of delivered electrical energy during the time of study

$338 \quad$ 5.3.2 Gas (Heat)

339 The amount of gas consumed for space and water heating in each dwelling over the three

340 year period is shown in Table 8.

341 Table 8: Total delivered gas against benchmarks and calculations

\begin{tabular}{cccccccc} 
& \multicolumn{3}{c}{$\begin{array}{c}\text { Total delivered gas } \\
\text { (kWh/yr) }\end{array}$} & \multicolumn{5}{c}{$\begin{array}{c}\text { Benchmarks \& calculations } \\
\text { (kWh/yr) } \\
\end{array}$} & Year 1 & Year 2 & Year 3 & $\begin{array}{c}\text { 3 year } \\
\text { average }\end{array}$ & SAP2009 & PHPP $\quad$ GB average & $\begin{array}{c}\text { Scottish } \\
\text { average }\end{array}$ \\
\hline & 2013 & 2014 & 2015 & & & & \\
\hline $\mathrm{CH}$ & 8,266 & 5,884 & 6,173 & 6,774 & 6,359 & - & 13,500 \\
$\mathrm{PH}$ & 5,875 & 6,739 & 6,226 & 6,280 & 4,821 & 1,480 & 13,872 \\
\hline
\end{tabular}

342 Gas consumption is variable across both dwellings, with the highest consumption found in

343 the $\mathrm{CH}$ during year one reduced by $29 \%$ and $26 \%$ in years two and three respectively. The

344 lowest consumption came from the $\mathrm{PH}$ during year one, it was $29 \%$ lower than the $\mathrm{CH}$, 345 however it increased in year two by $14 \%$ and by $5 \%$ in year three. SAP2009 calculations are $3467 \%$ lower $(-415 \mathrm{kWh})$ and $30 \%$ lower $(-1,459 \mathrm{kWh})$ than the delivered three year average for 347 the $\mathrm{CH}$ and $\mathrm{PH}$ respectively. There is no obvious explanation for this, except that the 
348 occupant behaviour in this dwelling has a significant impact on how energy is consumed. 349 Figure 24 further explains the distribution of delivered gas for heating over the period of study.

350 The $\mathrm{CH}$ has consumed more during its first year of occupation adjusting itself in subsequent 351 years, to $60 \mathrm{kWh} / \mathrm{m}^{2} / \mathrm{yr}$ in years two and three. The $\mathrm{PH}$ started low and increased by $35210 \mathrm{kWh} / \mathrm{m}^{2} / \mathrm{yr}$ between year one and two later falling closer to the year one consumption 353 during the last year of monitoring.

354

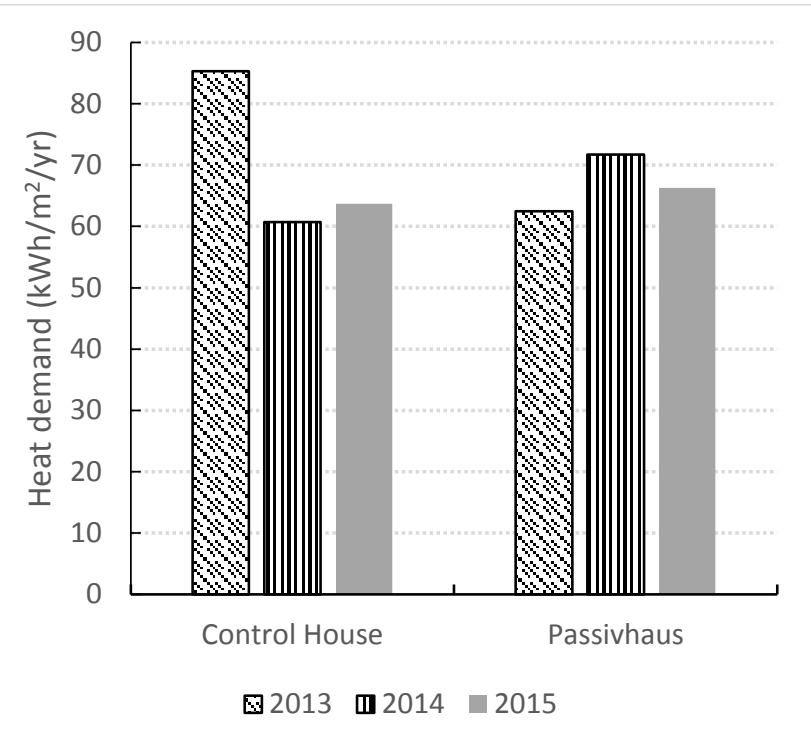

355 Figure 24: Distribution of delivered heat energy during the time of study

356 The results indicate that whilst there is variability in the consumption of gas across the three 357 years of monitoring, there is a downward trend in consumption with both dwellings consuming 358 a similar three year average. It is clear that the $\mathrm{CH}$ suffered the most during the colder winter 359 of $2012 / 13$ with increased gas consumption approximately $25 \mathrm{kWh} / \mathrm{m}^{2} / \mathrm{yr}$ higher than 360 subsequent years. The $\mathrm{PH}$ has shown that despite being designed with an envelope of lower 361 thermal transmission, the last year has consumed similarly than the less efficient $\mathrm{CH}$.

$362 \quad 5.4 \quad$ Carbon emissions \& cost 
363 Relevant to the environmental impact of the homes are the carbon emissions attributed to 364 the excess energy consumed against the design calculations. Taking the normalised 365 performance indices averaged over the three years, a comparison can be made. The $\mathrm{CH}$ has 366 a combined emission of $27 \mathrm{kgCO}_{2} / \mathrm{m}^{2} / \mathrm{yr}$ against the design aspiration $34 \mathrm{kgCO} / \mathrm{m}^{2} / \mathrm{yr}$. The $367 \mathrm{PH}$ has a combined emission of $34 \mathrm{kgCO} / \mathrm{m}^{2} / \mathrm{yr}$ compared with $32 \mathrm{kgCO} / \mathrm{m}^{2} / \mathrm{yr}$. The $\mathrm{PH}$ has 368 a higher carbon impact largely attributed to the higher electricity consumption, increased 369 occupant numbers and behaviour with greater non-regulated electricity use, shown in Figure $370 \quad 25$

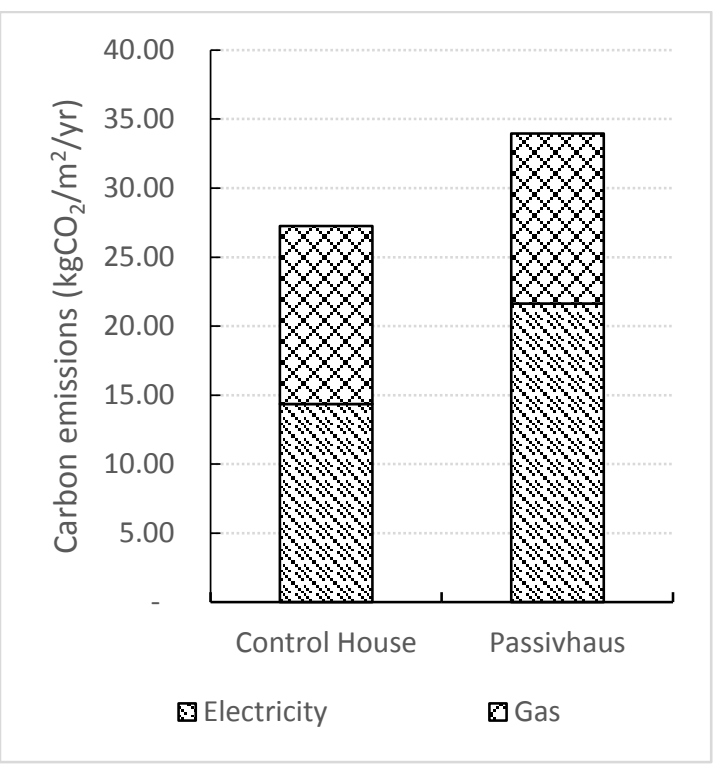

372

Figure 25: Duel fuel carbon impact of the properties over the analysed period of study

373 Higher energy demand impacts on occupant's fuel costs. Using the cost of fuel for heating a 374 property, the $\mathrm{CH}$ average expenditure over the three years of occupation came to $€ 360 / \mathrm{yr}$ 375 while the $\mathrm{PH}$ was $€ 333 / \mathrm{yr}$. This represented a difference against the SAP2009 calculations 376 of $€ 51$ in the $\mathrm{CH}$ and $€ 106$ in the $\mathrm{PH}$. The average Scottish expenditure on heat is $€ 790 / \mathrm{yr}$ 377 which represents a saving of $€ 430 / \mathrm{yr}$ in the $\mathrm{CH}$ and $€ 450 / \mathrm{yr}$ for the $\mathrm{PH}$. 
380 This study set out to evaluate the actual performance of two homes designed to meet 381 Passivhaus and SBS 2010 criteria. Comprehensive fabric performance and delivered energy 382 was collected during a three year continuous cycle. The analysis of the collected data show 383 a number of key findings which are summarised below.

384 Measured data of environmental conditions in both dwellings were found to reside within 385 normal and predicted ranges and neither property created identifiable conditions that were likely to be unhealthy to the occupants. The measured parameter of internal temperature showed some variation across the homes indicating how occupancy influences the comfort conditions and subsequent use of energy. Given the small sample analysed, these variations need to be compared with larger data sets of similar properties in order to identify significant 390 trends in the data. However, distinctions between the two properties led to a recognition that 391 fabric efficiency plays an important role in minimising fluctuations of internal temperatures; 392 contributing to a decline in thermal comfort.

393 The results from the fabric performance tests showed that the homes performed differently 394 to expectations and calculations. However, evaluation of the homes after occupation has 395 shown that the envelope was susceptible to poor maintenance and envelope deterioration 396 was observed over time. This was particularly evident with the air leakage results for both 397 homes; with increasing air permeability recorded each year from the initial tests conducted in 398 2014, particularly in the $\mathrm{PH}$. Thermal transmission in the $\mathrm{CH}$ has also increased since the 399 initial design. Possibly due to reduced performance of the insulation and open timber frame 400 panel system. However the $\mathrm{PH}$ wall performed as originally designed; perhaps showing 401 robustness and reliability of the system. 
402 Moreover, the results generally support previous work in the field $[3-5,87][33]$, though there 403 are four key areas which stand out, as indicated below:

405 Previous studies have shown that performance of low energy homes relies on the initial 406 quality of the design. The impact of assumed data over actual figures represent differences 407 in final as-built energy use. The properties present some differences between data used for 408 calculations and actual monitored data which impact on final energy demand. This further 409 demonstrates that compliance tools are limited in terms of the data used and are unable to 410 accommodate realistic scenarios of occupation and weather patterns.

\section{$411 \quad 6.2$ Specification, construction phase, commissioning}

412 The performance of the homes is also influenced by the interpretation of specifications, build 413 quality, and the correct installation of the building services; highlighting the importance 414 between the interaction of technology and the end user. Usability of services technology 415 requires clear guidance on their design and operation and recognising when maintenance is 416 required. Although a handover procedure took place where explanations of technology were 417 made [62], the user often felt detached from the controls, operation and maintenance of such 418 technology, partly due to its complexity but also because liabilities between owner (social 419 landlord) and occupant are misunderstood. This causes confusion, frustration and leads to 420 greater energy use.

421 The role of the construction phase and the quality of its contractors and builders to construct 422 the homes goes beyond the scope of this research, however poor interpretation of 423 specifications and the skill level of trades and contractors can have a large impact on energy 424 use once occupied. The only realistic way of quantifying this is by conducting construction 
425 performance checks and tests, such as those proposed by Guerra-Santin et al., [29] and 426 Littlewood \& Smallwood, [93] where poorly-performing fabric conditions can be corrected at 427 set stages, further refining its performance to match intended specification. Improving the 428 workforce skills can also help to reduce construction stage faults and defects causing the 429 performance gap.

430 Adequately commissioning the services can also help to identify faults that impact on building 431 energy use before handover to residents. Reporting back to the residents on the faults 432 identified or malpractice can save energy in the future and further inform the residents on the 433 correct operability of such technology. Performing a second commissioning stage after initial 434 corrections have been made further provides confidence to the building owner and occupier 435 that the technology will perform as first planned.

\section{$436 \quad 6.3 \quad$ Occupant behaviour}

437 Taking account the small sample of monitored dwellings in this study and the variations in 438 occupant behaviour, the consumption of gas in the $\mathrm{CH}$ has been surprisingly close to that 439 assumed in the compliance models, however for the $\mathrm{PH}$ it is over4 times higher than the 440 PHPP calculations suggest and 25\% higher than SAP2009; highlighting the importance of 441 initial building design, construction quality, and occupant behaviour. Electrical demand over 442 the three years has shown that occupancy influences its usage, with disparities shown in the 443 assumed calculations, the $\mathrm{CH}$ is $55 \%$ lower than the benchmark obtained by Yohanis et al., 444 [62] and the $\mathrm{PH}$ is very close but nearly 2.5 times higher than that calculated in PHPP.

$445 \quad 6.4 \quad$ Impact of carbon emissions

446 The normalised as-built total carbon emissions emitted by the two homes in comparison with 447 other studies shows correlations and similarities. Comparisons with results by Ridley et al., 
448 [91] on two Passivhaus properties and Gill et al., [32] of four affordable low carbon homes 449 are shown in Figure 26. Another study by Stinson et al., [82] shows similar results for semi450 detached social rent homes built in 2010 , using timber open panel wall systems and no 451 renewable energy technology.

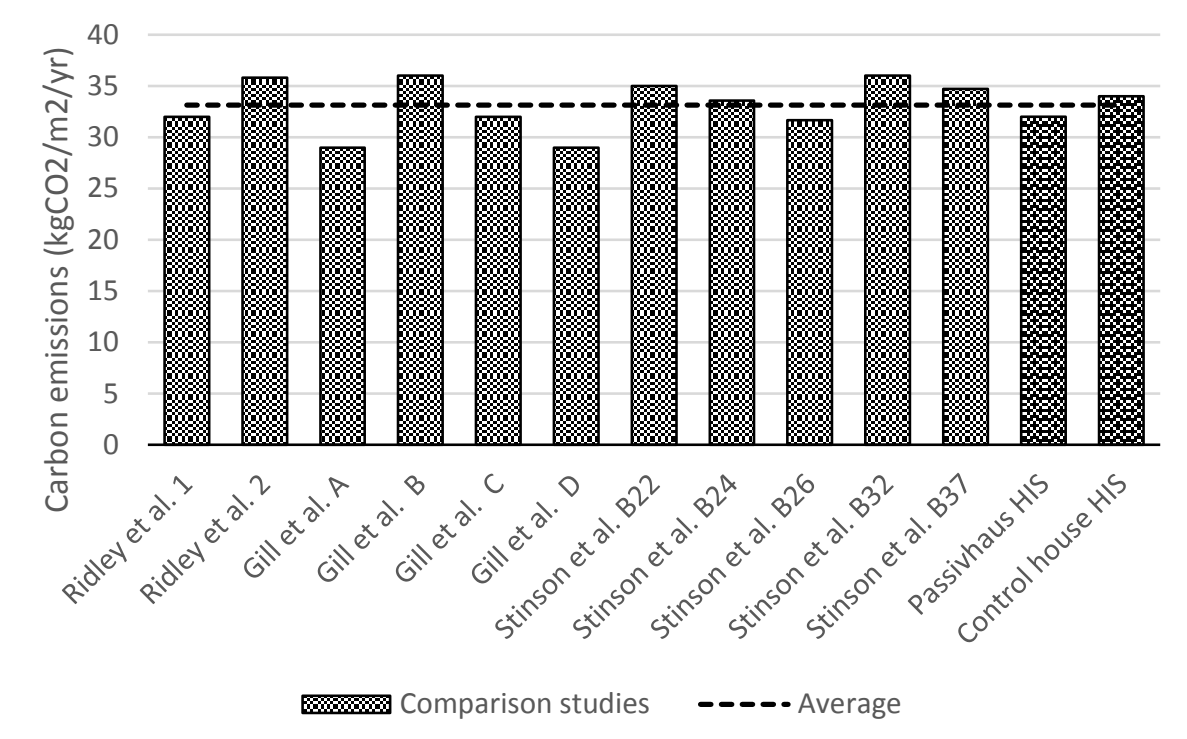

Figure 26: Carbon emissions against other similar homes

454 Out of the twenty seven homes in the KHA HIS development, this paper analyses a 455 statistically small, yet directly comparable, sample of low energy homes. Despite this, the 456 study contributes usefully to the comparison of the as-built performance against as-design 457 calculations by identifying important differences. Over a longer occupied period these 458 differences will not only exacerbate the dwellings environmental impact but also have a 459 detrimental effect on occupant's health, wellbeing and energy consumption.

460 Drawing conclusions from these results with respect to wider domestic housing stock or 461 carbon policy measures in the UK is difficult, however the results do reveal that house building 462 practices need to change in order to achieve stated carbon reduction targets. 
463 Further building performance evaluation and post-occupancy evaluation work is being 464 conducted in order to assess the occupant's impact on the overall performance of these two 465 homes as well as others in the HIS development. The larger sample size of this enhanced 466 study into the different methods of construction in the development will give a greater 467 appreciation of the performance of current housebuilding in the UK; determining the impact 468 of the users and the role that dilapidation of the building fabric performance has on actual 469 energy performance over time.

\section{Acknowledgements}

471 Kingdom Housing Association, Campion Homes Ltd, Scottish Passive House Centre, Stuart 472 King Architecture \& Design, Oliver \& Robb Architects, and Scotframe Timber Engineering.

474 This research did not receive any specific grant from funding agencies in the public, 475 commercial, or not-for-profit sectors.

9. Appendices

477 Appendix A: Test equipment and methodology specifications

\begin{tabular}{|c|c|c|c|c|c|c|c|}
\hline $\begin{array}{l}\text { Test } \\
\text { equipment }\end{array}$ & Make & Model & $\begin{array}{l}\text { Calibrati } \\
\text { on type }\end{array}$ & Accuracy & Range & $\begin{array}{l}\text { Logging } \\
\text { interval }\end{array}$ & Guidance \\
\hline Blower Door & Energy & Minneapolis & UKAS & $\pm 7 \%$ & - & - & ATTMA, \\
\hline Fan & Conservation & - Model 3 & (Yearly) & & & & $\begin{array}{l}2010 \& \text { BS } \\
\text { EN } \\
13829: 2001\end{array}$ \\
\hline Micro- & Energy & DG-700 & UKAS & $\pm 2 \mathrm{~Pa}$ & $0-100$ & - & ATTMA, \\
\hline manometer & Conservation & & (Yearly) & & Pascals & & 2010 \& BS \\
\hline
\end{tabular}




\begin{tabular}{|c|c|c|c|c|c|c|c|}
\hline & & & & & & & $\begin{array}{l}\text { EN } \\
13829: 2001\end{array}$ \\
\hline Thermometer & Testo & 110 & $\begin{array}{l}\text { UKAS } \\
\text { (Yearly) }\end{array}$ & $\pm 1^{\circ} \mathrm{C}$ & $\begin{array}{l}-20^{\circ} \mathrm{C}- \\
+40^{\circ} \mathrm{C}\end{array}$ & $\begin{array}{l}\text { Spot } \\
\text { measur } \\
\text { ements }\end{array}$ & $\begin{array}{l}\text { ATTMA, } \\
2010 \& \text { BS } \\
\text { EN } \\
\text { 13829:2001 }\end{array}$ \\
\hline Barometer & Druck & DPI 705 & $\begin{array}{l}\text { UKAS } \\
\text { (Yearly) }\end{array}$ & \pm 5 mbar & $\begin{array}{l}950- \\
1050 \\
\text { mbar }\end{array}$ & $\begin{array}{l}\text { Spot } \\
\text { measur } \\
\text { ements }\end{array}$ & $\begin{array}{l}\text { ATTMA, } \\
2010 \& \text { BS } \\
\text { EN } \\
\text { 13829:2001 }\end{array}$ \\
\hline Anemometer & Skywatch & Xplorer 2 & - & $\begin{array}{l}<20 \mathrm{~m} / \mathrm{s}=3 \\
\%\end{array}$ & $\begin{array}{l}0.8-40 \\
\mathrm{~m} / \mathrm{s}\end{array}$ & $\begin{array}{l}\text { Spot } \\
\text { measur } \\
\text { ements }\end{array}$ & - \\
\hline Smoke test & Hayes UK & - & - & - & - & - & - \\
\hline Data logger & Grant & SQ2020 \& & - & $\pm 0.05 \%$ & - & $5 \mathrm{~min}$ & - \\
\hline 24 bit & Squirrel & SQ2010 & & $\& 0.1 \%$ & & & \\
\hline $\begin{array}{l}\text { Heat flow } \\
\text { mats }\end{array}$ & Hukseflux & HFP01 & $\begin{array}{l}\text { ISO (bi- } \\
\text { annual) }\end{array}$ & $\pm 3 \%$ & $\begin{array}{l}-0.075 \\
\text { to } 0.075 \\
\mathrm{~V}\end{array}$ & $5 \mathrm{~min}$ & $\begin{array}{l}\text { ASTM C177 } \\
\text { - ISO } 8302\end{array}$ \\
\hline $\begin{array}{l}\text { Thermo- } \\
\text { couples }\end{array}$ & $\begin{array}{l}\text { RS } \\
\text { Components }\end{array}$ & $\begin{array}{l}\text { K-type: } \\
\text { Chromel - } \\
\text { alumel - } 41 \\
\mu \mathrm{V} /{ }^{\circ} \mathrm{C}\end{array}$ & $\begin{array}{l}\text { In- } \\
\text { house }\end{array}$ & $\pm 1.5^{\circ} \mathrm{C}$ & $\begin{array}{l}200 \text { to } \\
1372^{\circ} \mathrm{C}\end{array}$ & $5 \mathrm{~min}$ & $\begin{array}{l}\text { IEC } \\
60584\end{array}$ \\
\hline $\begin{array}{l}\text { Thermal } \\
\text { camera }\end{array}$ & FLIR & $\begin{array}{l}\text { B335 - } \\
320 \times 240 \\
\text { pixel } \\
\text { resolution }\end{array}$ & ISO & - & $\begin{array}{l}70 \mathrm{mK} \\
\text { to }<50 \\
\mathrm{mK} .\end{array}$ & - & $\begin{array}{l}\text { BS EN } \\
13187: 1999\end{array}$ \\
\hline $\begin{array}{l}\text { Temperature } \\
\text { \& Humidity }\end{array}$ & Gemini & $\begin{array}{l}\text { Tinytag Ultra } \\
\text { TGU-4017 }\end{array}$ & ISO & $\begin{array}{l} \pm 0.5 \text { to } \\
0.4^{\circ} \mathrm{C}\end{array}$ & $\begin{array}{l}-40^{\circ} \mathrm{C} \text { to } \\
+85^{\circ} \mathrm{C}\end{array}$ & $5 \mathrm{~min}$ & - \\
\hline
\end{tabular}


479 Appendix B: Household domestic energy consumption benchmarks - Semi-detached home.

\begin{tabular}{|c|c|c|c|c|c|c|c|c|}
\hline \multirow{3}{*}{$\begin{array}{l}\text { Benchmark } \\
\text { name }\end{array}$} & \multirow{3}{*}{ Date } & \multirow{3}{*}{ Author } & \multirow{3}{*}{ Origin } & \multirow{3}{*}{$\begin{array}{l}\text { Household } \\
\text { type or } \\
\text { archetype }\end{array}$} & \multicolumn{4}{|c|}{ Benchmark } \\
\hline & & & & & \multicolumn{2}{|c|}{ Heat } & \multicolumn{2}{|c|}{ Electricity } \\
\hline & & & & & $\mathrm{kWh} / \mathrm{yr}$ & $\mathrm{kWh} / \mathrm{m}^{2}$ & $\mathrm{kWh} / \mathrm{yr}$ & $\mathrm{kWh} / \mathrm{m}^{2}$ \\
\hline $\begin{array}{l}\text { Real-life } \\
\text { energy use } \\
\text { in the UK }\end{array}$ & 2008 & $\begin{array}{l}\text { Yohanis } \\
\text { et al. }\end{array}$ & $\begin{array}{l}\text { Peer } \\
\text { reviewed } \\
\text { journal }\end{array}$ & $\begin{array}{l}\text { Semi- } \\
\text { detached } \\
\text { house }\left(97 \mathrm{~m}^{2}\right)\end{array}$ & - & - & 4,656 & 40 \\
\hline DIMPSA & 2014 & White & DEFRA & $\begin{array}{l}\text { Younger } \\
\text { working } \\
\text { families in } \\
\text { medium- } \\
\text { sized rented } \\
\text { houses }\end{array}$ & 13,595 & - & 3,491 & - \\
\hline DIMPSA & 2014 & White & DEFRA & $\begin{array}{l}\text { "Average" } \\
\text { mains gas- } \\
\text { heated } \\
\text { households }\end{array}$ & 15,280 & - & 3,585 & - \\
\hline $\begin{array}{l}\text { Intertek } \\
\text { report }\end{array}$ & 2012 & $\begin{array}{l}\text { Zimmermann } \\
\text { et al. }\end{array}$ & $\begin{array}{l}\text { DECC, } \\
\text { DEFRA }\end{array}$ & $\begin{array}{l}\text { Semi- } \\
\text { detached }\end{array}$ & - & - & 4,009 & 76 \\
\hline R66141 & & & $\& E S T$ & house & & & & \\
\hline $\begin{array}{l}\text { Intertek } \\
\text { report }\end{array}$ & 2012 & $\begin{array}{l}\text { Zimmermann } \\
\text { et al. }\end{array}$ & $\begin{array}{l}\text { DECC, } \\
\text { DEFRA }\end{array}$ & $\begin{array}{l}\text { Household } \\
\text { with children }\end{array}$ & - & - & 3,672 & 68 \\
\hline R66141 & & & \& EST & & & & & \\
\hline
\end{tabular}




\begin{tabular}{|c|c|c|c|c|c|c|c|c|}
\hline $\begin{array}{l}\text { Intertek } \\
\text { report }\end{array}$ & 2012 & $\begin{array}{l}\text { Zimmermann } \\
\text { et al. }\end{array}$ & $\begin{array}{l}\text { DECC, } \\
\text { DEFRA }\end{array}$ & $\begin{array}{l}\text { Multiple } \\
\text { person }\end{array}$ & - & - & 4,232 & 77 \\
\hline $\mathrm{R} 66141$ & & & \& EST & $\begin{array}{l}\text { household } \\
\text { with no } \\
\text { dependent } \\
\text { children }\end{array}$ & & & & \\
\hline $\begin{array}{l}\text { Sub-national } \\
\text { - GB }\end{array}$ & 2014 & DECC & DECC & $\begin{array}{l}\text { GB mean, } \\
\text { weather } \\
\text { corrected }\end{array}$ & 13,500 & - & 4,100 & - \\
\hline $\begin{array}{l}\text { Sub-national } \\
\text { - Scotland }\end{array}$ & 2012 & DECC & DECC & $\begin{array}{l}\text { Scotland } \\
\text { mean }\end{array}$ & 14,826 & - & 4,577 & - \\
\hline $\begin{array}{l}\text { Sub-national } \\
\text { - Scotland }\end{array}$ & 2014 & DECC & DECC & $\begin{array}{l}\text { Scotland } \\
\text { mean }\end{array}$ & 13,872 & - & 3,915 & - \\
\hline ECUK & 2014 & DECC & DECC & $\begin{array}{l}\text { UK } \\
\text { (unweather } \\
\text { corrected) }\end{array}$ & 14,100 & - & 4,150 & - \\
\hline ECUK & 2014 & DECC & DECC & $\begin{array}{l}\text { UK (weather } \\
\text { corrected) }\end{array}$ & 12,300 & - & 4,000 & - \\
\hline NEED - UK & 2013 & DECC & DECC & $\begin{array}{l}\text { Estimates } \\
\text { removed }\end{array}$ & 13,600 & - & 4,000 & - \\
\hline
\end{tabular}

[1] C. Foulds, J. Powell, G. Seyfang, Investigating the performance of everyday domestic practices using building monitoring, Building Research \& Information. 41 (2013) 622-636. doi:10.1080/09613218.2013.823537.

[2] D. Johnston, D. Farmer, M. Brooke-Peat, D. Miles-Shenton, Bridging the domestic building fabric performance gap, Building Research \& Information. 3218 (2014) 1-14. doi:10.1080/09613218.2014.979093.

[3] L. Itard, D. Majcen, H. Visscher, Energy Labels in Dutch Dwellings A comparison with the 489 actual heating energy consumption, in: PLEA2012 - 28th Conference, Opportunities, Limits \& 
Needs Towards an Environmentally Responsible Architecture Lima, Perú 7-9 November 2012, 2012: p. 6.

[4] O. Guerra-Santin, L. Itard, H. Visscher, The effect of occupancy and building characteristics on energy use for space and water heating in Dutch residential stock, Energy and Buildings. 41 (2009) 1223-1232. doi:10.1016/j.enbuild.2009.07.002.

[5] J. Rekstad, M. Meir, E. Murtnes, A. Dursun, A comparison of the energy consumption in two passive houses, one with a solar heating system and one with an air-water heat pump, Energy and Buildings. 96 (2015) 149-161. doi:10.1016/j.enbuild.2015.02.059.

[6] T.R. Sharpe, J. Foster, A. Poston, Monitored environmental conditions in new energy efficient housing in Scotland - effects by and on occupants, International Seminar on Renewable Energy and Sustainable Development. 2 (2015) 1-6.

[7] L. Itard, F. Meijer, Towards a sustainable Northern European housing stock, IOS Press BV, Delf, The Netherlands, 2008.

[8] The Scottish Government, Energy in Scotland 2014, a compendium of Scottish energy statistics and information, Edinburgh, 2014.

[9] EU Parliament, Directive 2010/30 \& 31/EU of the European Parliament and of the Council of 19 May 2010, Official Journal of the European Union - L153. 53 (2010) 40.

[10] J. Kurnitski, A. Saari, T. Kalamees, M. Vuolle, J. Niemelä, T. Tark, Cost optimal and nearly zero (nZEB) energy performance calculations for residential buildings with REHVA definition for nZEB national implementation, Energy and Buildings. 43 (2011) 3279-3288. doi:10.1016/j.enbuild.2011.08.033.

[11] F. Stevenson, J. Lomas, T. Gordon, Monitoring Guide for Carbon Emissions, Energy and Water Use, London, 2010.

[12] S. Pretlove, S. Kade, Post occupancy evaluation of social housing designed and built to Code for Sustainable Homes levels 3, 4 and 5, Energy and Buildings. 110 (2016) 120-134. doi:10.1016/j.enbuild.2015.10.014.

[13] SBS, Scottish Building Standards - Technical Handbook - Domestic Section 7 Sustainability 2011, Livingston, 2011.

[14] L. Sullivan, A Low Carbon Building Standards Strategy For Scotland, Arcamedia - Crown Copyright 2007, Livingston, 2007. doi:ISBN: 978-1-904320-06-7.

[15] E. Heffernan, W. Pan, X. Liang, DELIVERING ZERO CARBON HOMES IN THE UK, Arcom.ac.uk. (2012) 1445-1454.

[16] R.S. McLeod, C.J. Hopfe, Y. Rezgui, An investigation into recent proposals for a revised definition of zero carbon homes in the UK, Energy Policy. 46 (2012) 25-35. doi:10.1016/j.enpol.2012.02.066.

[17] BRE \& DECC, SAP 2009 - The Government' s Standard Assessment Procedure for Energy Rating of Dwellings, Watford, 2011.

[18] S. Kelly, D. Crawford-Brown, M.G. Pollitt, Building performance evaluation and certification in the UK: Is SAP fit for purpose?, Renewable and Sustainable Energy Reviews. 16 (2012) 6861-6878. doi:10.1016/j.rser.2012.07.018.

[19] G. Murphy, M. Kummert, B. Anderson, J. Counsell, A comparison of the UK Standard Assessment Procedure and detailed simulation of solar energy systems for dwellings, Journal of Building Performance Simulation. 4 (2011) 75-90.

[20] G. Sutherland, E. Maldonado, P. Wouters, M. Papaglastra, Implementing the Energy Performance of Buildings Directive (EPBD), Second, ADENE, Porto, 2013.

[21] SBS, Scottish Building Standards - Technical Handbook - Domestic Section 6 Energy, Edinburgh, 2013.

[22] J. Castellano, D. Castellano, A. Ribera, J. Ciurana, Developing a Simplified Methodology to 
[23] W. Feist, J. Schnieders, V. Dorer, A. Haas, Re-inventing air heating: Convenient and comfortable within the frame of the Passive House concept, Energy and Buildings. 37 (2005) 1186-1203. doi:10.1016/j.enbuild.2005.06.020.

[24] L. Müller, T. Berker, Passive House at the crossroads: The past and the present of a voluntary standard that managed to bridge the energy efficiency gap, Energy Policy. 60 (2013) 586-593. doi:10.1016/j.enpol.2013.05.057.

[25] L. Reason, A. Clarke, Projecting Energy Use and CO2 Emissions from Low Energy Buildings - A Comparison of the Passivhaus Planning Package (PHPP) and SAP, London, 2008.

[26] I. Ridley, A. Clarke, J. Bere, H. Altamirano, S. Lewis, M. Durdev, A. Farr, The monitored performance of the first new London dwelling certified to the Passive House standard, Energy and Buildings. 63 (2013) 67-78. doi:10.1016/j.enbuild.2013.03.052.

[27] F. Musau, G. Deveci, From targets to occupied low carbon homes: assessing the challenges of delivering low carbon affordable housing., ... Conference on Passive and Low Energy .... (2011) 13-15.

[28] G. Murphy, P. Tuohy, MONITORING AND MODELLING THE FIRST PASSIVE HOUSE IN SCOTLAND, Ibpsa.org. (2013) 2390-2397.

[29] O. Guerra-Santin, C. Tweed, H. Jenkins, S. Jiang, Monitoring the performance of low energy dwellings: Two UK case studies, Energy and Buildings. 64 (2013) 32-40. doi:10.1016/j.enbuild.2013.04.002.

[30] J. Wingfield, D.M.-S. Malcolm Bell, Bob Lowe, T. South, Lessons from Stamford Brook Understanding the Gap between Designed \& Real Performance - Final Report, 2009.

[31] Z.M. Gill, M.J. Tierney, I.M. Pegg, N. Allan, Low-energy dwellings: the contribution of behaviours to actual performance, Building Research \& Information. 38 (2010) 491-508. doi:10.1080/09613218.2010.505371.

[32] A. Menezes, A. Cripps, D. Bouchlaghem, R. Buswell, Predicted vs. actual energy performance of non-domestic buildings, Applied Energy. (2011).

[33] P. de Wilde, The gap between predicted and measured energy performance of buildings: A framework for investigation, Automation in Construction. 41 (2014) 40-49. doi:10.1016/j.autcon.2014.02.009.

[34] P. de Wilde, W. Tian, The role of adaptive thermal comfort in the prediction of the thermal performance of a modern mixed-mode office building in the UK under climate change, Journal of Building Performance Simulation. 3 (2010) 87-101. doi:10.1080/19401490903486114.

[35] M. Baborska-Narozny, F. Stevenson, Continuous Mechanical Ventilation in Housing Understanding the Gap between Intended and Actual Performance and Use, Energy Procedia. 83 (2015) 167-176. doi:10.1016/j.egypro.2015.12.207.

[36] P. de Wilde, W. Tian, G. Augenbroe, Longitudinal prediction of the operational energy use of buildings, Building and Environment. 46 (2011) 1670-1680. doi:10.1016/j.buildenv.2011.02.006.

[37] M. Shamash, A. Mylona, G. Metcalf, What Guidance Will Building Modellers Require For Integrating, First Building Simulation and Optimization Conference, IBPSA-England. (2012) 253-260.

[38] E.P. Mora, Life cycle, sustainability and the transcendent quality of building materials, Building and Environment. 42 (2007) 1329-1334. doi:http://dx.doi.org/10.1016/j.buildenv.2005.11.004.

[39] J.R. Littlewood, I. Smallwood, Testing Building Fabric Performance and the Impacts Upon Occupant Safety, Energy Use and Carbon Inefficiencies in Dwellings, Energy Procedia. 83 (2015) 454-463. doi:10.1016/j.egypro.2015.12.165. 
[40] J. Glass, A.R.J.J. Dainty, A.G.F.F. Gibb, New build: Materials, techniques, skills and $\begin{array}{lllll}\text { innovation, } & \text { Energy } & \text { Policy. } & 36 & \text { (2008) }\end{array}$ doi:http://dx.doi.org/10.1016/j.enpol.2008.09.016.

[41] E. Heffernan, W. Pan, X. Liang, P. de Wilde, Zero carbon homes: Perceptions from the UK construction industry, Energy Policy. 79 (2015) 23-36. doi:10.1016/j.enpol.2015.01.005.

[42] O. Guerra-Santin, Behavioural patterns and user profiles related to energy consumption for heating, Energy and Buildings. 43 (2011) 2662-2672. doi:10.1016/j.enbuild.2011.06.024.

[43] R. Galvin, Making the "rebound effect" more useful for performance evaluation of thermal retrofits of existing homes: Defining the "energy savings deficit" and the "energy performance gap," Energy and Buildings. 69 (2014) 515-524. doi:10.1016/j.enbuild.2013.11.004.

[44] N.K. Ghosh, M.F. Blackhurst, Energy savings and the rebound effect with multiple energy services and efficiency correlation, Ecological Economics. 105 (2014) 55-66. doi:10.1016/j.ecolecon.2014.05.002.

[45] J.S. Bourrelle, Zero energy buildings and the rebound effect: A solution to the paradox of energy efficiency?, Energy and Buildings. 84 (2014) 633-640. doi:10.1016/j.enbuild.2014.09.012.

[46] R. Galvin, The Rebound Effect in Home Heating: A Guide for Policymakers and Practitioners, First, Routledge, Abingdon, Oxon, 2015.

[47] R. Gupta, S. Chandiwala, Understanding occupants: feedback techniques for large-scale lowcarbon domestic refurbishments, Building Research \& Information. (2010) 37-41. doi:10.1080/09613218.2010.495216.

[48] F. Stevenson, A. Leaman, Evaluating housing performance in relation to human behaviour: new challenges, Building Research \& Information. $38 \quad$ (2010) 437-441. doi:10.1080/09613218.2010.497282.

[49] A. Leaman, B. Bordass, Assessing building performance in use 4: the Probe occupant surveys and their implications, Building Research \& Information. 29 (2001) 129-143. doi:10.1080/09613210010008045.

[50] B. Bordass, R. Cohen, J. Field, Energy performance of non-domestic buildings: closing the credibility gap, Building Performance Congress. (2004).

[51] E. Burman, D. Mumovic, J. Kimpian, Towards measurement and verification of energy performance under the framework of the European directive for energy performance of buildings, Energy. 77 (2014) 153-163. doi:10.1016/j.energy.2014.05.102.

[52] F. Stevenson, H.B. Rijal, Developing occupancy feedback from a prototype to improve housing production, Building Research \& Information. 38 (2010) 549-563. doi:10.1080/09613218.2010.496182.

[53] G.-S. Olivia, T.A. Christopher, In-use monitoring of buildings: An overview and classification of evaluation methods, Energy and Buildings. 86 (2015) 176-189. doi:10.1016/j.enbuild.2014.10.005.

[54] F. Stevenson, N. Williams, Longitudinal evaluation of affordable housing in Scotland: lessons for low energy features, ... Low Energy .... (2007) 617-623.

[55] P. Jones, S. Lannon, J. Patterson, Retrofitting existing housing: how far, how much?, Building Research \& Information. 41 (2013) 532-550. doi:10.1080/09613218.2013.807064.

[56] Y.G. Yohanis, J.D. Mondol, A. Wright, B. Norton, Real-life energy use in the UK: How occupancy and dwelling characteristics affect domestic electricity use, Energy and Buildings. 40 (2008) 1053-1059. doi:10.1016/j.enbuild.2007.09.001.

[57] V. White, S. Roberts, I. Preston, "Beyond average consumption" Development of a framework for assessing impacts of policy proposls on different consumer groups, (2012) 1-35.

[58] V. White, "Beyond average consumption" Development of a framework for assessing impacts of policy proposls on different consumer groups - Updated report, (2014) 1-35. 

Electricity Survey A study of domestic electrical product usage, Milton Keynes, 2012.

[60] DECC, Sub-national electricity and gas consumption statistics, London, 2015.

[61] DECC, Domestic NEED Methodology, Department of Energy \& Climate Change, London, 2015.

[62] M. Jack, J. Currie, J. Bros-Williamson, J. Stinson, Housing Innovation Showcase 2012: Building Performance Evaluation, Phase 1-Part 1, Edinburgh, 2013. doi:10.14297/enr.2013.000001.

[63] J. Bros-Williamson, J. Currie, J. Stinson, Housing Innovation Showcase 2012: Building Performance Evaluation, Phase 1 - Part 2 - Post Occupancy Evaluation First Year of Occupation, Edinburgh, 2014.

[64] SBS, Scottish Building Regulations - Section 6 Energy, Livingston, 2010.

[65] BS EN, British Standard 13829 - Thermal performance of buildings - Determination of air permeability of buildings - Fan pressurization method, Brussels, 2001. doi:ISBN 058036935 8.

[66] ATTMA, Measuring Air Permeability of Dwellings, Nothhampton, 2010.

[67] D. Sinnott, M. Dyer, Air-tightness field data for dwellings in Ireland, Building and Environment. 51 (2012) 269-275. doi:10.1016/j.buildenv.2011.11.016.

[68] W. Pan, Relationships between air-tightness and its influencing factors of post-2006 new-build dwellings in the UK, Building and Environment. 45 (2010) 2387-2399. doi:10.1016/j.buildenv.2010.04.011.

[69] H. Okuyama, Y. Onishi, Reconsideration of parameter estimation and reliability evaluation methods for building airtightness measurement using fan pressurization, Building and Environment. 47 (2012) 373-384. doi:10.1016/j.buildenv.2011.06.027.

[70] M.C. Gillott, D.L. Loveday, J. White, C.J. Wood, K. Chmutina, K. Vadodaria, Improving the airtightness in an existing UK dwelling: The challenges, the measures and their effectiveness, Building and Environment. 95 (2016) 227-239. doi:10.1016/j.buildenv.2015.08.017.

[71] J. Wood, L. Kovacova, Enegroup LCBT Gateway Animation, (2013). https://youtu.be/KLJv03mPDGY (accessed January 13, 2016).

[72] BSI, ISO 9869-1:2014- Thermal insulation — Building elements — Insitu measurement of thermal resistance and thermal transmittance; Part 1: Heat flow meter method, Geneva, 2014.

[73] P. Baker, Technical Paper 10: U-values and traditional buildings - In situ measurements and their comparisons to calculated values, Glasgow, 2011.

[74] Hukseflux Thermal Sensors, Hukseflux Thermal Sensors - User manual: HFP01/ HFP03 manual version 0612, (2006) 1-35.

[75] J. Hulme, S. Doran, In-situ measurements of wall U-values in English housing, 44 (2014).

[76] BS EN, British Standard 13187 - Thermal performance of buildings - Qualitative detection of thermal irregularities in building envelopes, Brussels, 1999.

[77] T. Taylor, J. Counsell, S. Gill, Energy efficiency is more than skin deep: Improving construction quality control in new-build housing using thermography, Energy and Buildings. 66 (2013) 222-231. doi:10.1016/j.enbuild.2013.07.051.

[78] C.A. Balaras, A.A. Argiriou, Infrared thermography for building diagnostics, Energy and Buildings. 34 (2002) 171-183. doi:10.1016/S0378-7788(01)00105-0.

[79] J.. Hart, An Introduction to infra-red thermography for building surveys - Latest research information and how to apply it, Garston, Watford, UK, 1990.

[80] T.Y. Lo, K.T.W. Choi, Building defects diagnosis by infrared thermography, Structural Survey. 22 (2004) 259-263. doi:10.1108/02630800410571571.

[81] J. Currie, J. Stinson, A. Willis, R.. Smith, EWGECO - Home Energy Display Trials: 
Questionnaire, Interview and Energy Use Comparison:, Edinburgh, 2011.

[82] J. Stinson, A. Willis, J. Bros-Williamson, J. Currie, S. Smith, Visualising energy use for smart homes and informed users, in: CENTRO CONGRESSI INTERNAZIONALE SRL. (Ed.), 6th International Building Physics Conference, IBPC 2015, Elsevier - AASRI Procedia, Torino, 2015: p. 6. doi:10.1016/j.egypro.2015.11.015.

[83] BS EN, EN 15217:2007 "Energy performance of buildings-methods for expressing energy performance and for energy certification of buildings," Brussels, 2007.

[84] T. O'Leary, M. Belusko, D. Whaley, F. Bruno, Review and evaluation of using household metered energy data for rating of building thermal efficiency of existing buildings, Energy and Buildings. 108 (2015) 433-440. doi:http://dx.doi.org/10.1016/j.enbuild.2015.09.018.

[85] I. Ridley, J. Bere, A. Clarke, Y. Schwartz, A. Farr, The side by side in use monitored performance of two passive and low carbon Welsh houses, Energy and Buildings. 82 (2014) 13-26. doi:10.1016/j.enbuild.2014.06.038.

[86] iPHA, The global Passive House platform, (2015). http://www.passivehouseinternational.org/index.php?page_id=65 (accessed January 7, 2016).

[87] D. Majcen, L.C.M. Itard, H. Visscher, Theoretical vs. actual energy consumption of labelled dwellings in the Netherlands: Discrepancies and policy implications, Energy Policy. 54 (2013) 125-136. doi:10.1016/j.enpol.2012.11.008.

[88] J.R. Littlewood, I. Smallwood, Testing Building Fabric Performance and the Impacts Upon Occupant Safety, Energy Use and Carbon Inefficiencies in Dwellings, Energy Procedia. 83 (2015) 454-463. doi:10.1016/j.egypro.2015.12.165.

[89] Z.M. Gill, M.J. Tierney, I.M. Pegg, N. Allan, Measured energy and water performance of an aspiring low energy/carbon affordable housing site in the UK, Energy and Buildings. 43 (2011) 117-125. doi:10.1016/j.enbuild.2010.08.025.

[90] CIBSE, CIBSE Guide A: Environmental Design, 8th ed., The Levenham Press Ltd, London, 2015. doi:10.1016/0360-1323(94)00059-2. 